\title{
Locally Born Olfactory Bulb Stem Cells Proliferate in Response to Insulin-Related Factors and Require Endogenous Insulin-Like Growth Factor-I for Differentiation into Neurons and Glia
}

\author{
Carlos Vicario-Abejón, María J. Yusta-Boyo, Carmen Fernández-Moreno, and Flora de Pablo \\ Group of Growth Factors in Vertebrate Development, Centro de Investigaciones Biológicas, Consejo Superior de Investigaciones Científicas, E-28006 \\ Madrid, Spain
}

\begin{abstract}
After late embryogenesis, new neurons are continuously added to the olfactory bulb (OB) from stem cells located in the forebrain subventricular zone. Nonetheless, stem cells have not been described within the embryonic olfactory bulb. Here we report the isolation of local olfactory bulb stem cells from the embryonic day 12.5-14.5 mouse embryo. These cells were $99.2 \%$ nestin positive and proliferated extensively in culture to at least 150 cell doublings. Clonal analysis demonstrated that neurons $\left(\mathrm{TuJ} 1^{+}\right)$, astrocytes $\left(\mathrm{GFAP}^{+}\right)$, and oligodendrocytes $\left(\mathrm{O}^{+}\right)$could be generated from single-plated cells, indicating that they are multipotent. At least $90 \%$ of proliferating cells expressed insulin-like growth factor-I (IGF-I), (pro)insulin, and their cognate receptors; these growth factors collaborated with fibroblast growth factor-2 plus epidermal growth factor (EGF) to promote stem cell proliferation and sphere formation. Cells from $I g f-I^{-1-}$ mice, however, proliferated as extensively as did $I g f-I^{+/+}$cells. Differentiation and survival of stem cell-generated neurons and glia showed strong dependence on exogenous IGF-I, but oligodendrocyte differentiation also required insulin at low concentration. Furthermore, the percentages of stem cell-generated neurons, astrocytes, and oligodendrocytes were markedly lower in the cultures prepared from the Igf-I $I^{-1-}$ mice compared with those of $I g f-I^{+/+}$. Concordantly, lack of IGF-I resulted in abnormal formation of the olfactory bulb mitral cell layer and altered radial glia morphology. These results support the presence within the embryonic mouse olfactory bulb of stem cells with specific requirements for insulin-related growth factors for proliferation or differentiation. They demonstrate that IGF-I is an endogenous factor regulating the differentiation of stem and other precursor cells within the olfactory bulb.
\end{abstract}

Key words: olfactory bulb stem cells; mitral neurons; IGF-I; insulin; proinsulin; proliferation; differentiation

\section{Introduction}

At early stages of embryonic development, many neuroepithelial precursor cells in the vertebrate nervous system have the potential to differentiate into neurons, astrocytes, and oligodendrocytes and the ability to self-renew, indicating that they are neural stem cells (McKay, 1997; Gage, 2000; Temple, 2001). Signals that promote precursor and stem cell maintenance and fate specification will influence the final numbers of neurons and glia formed during CNS development (Lillien, 1998; Edlund and Jessell, 1999).

Insulin-like growth factor-I (IGF-I) is a secreted protein related to IGF-II as well as to insulin and its unprocessed precursor, proinsulin (De Pablo and de la Rosa, 1995). We reported previ-

\footnotetext{
Received Aug. 27, 2002; revised 0ct. 31, 2002; accepted Nov. 1, 2002.

This work was funded by Grants PM97-0143 and BMC 2001-2132 from the Ministries Ministerio de Educación y Ciencia and Ministerio de Ciencia y Tecnología (MCYT) (Spain) to F.deP. C.V.-A. is an investigator of the Programa Ramón y Cajal from the MCYT, M.J.Y.-B. is a doctoral Fellow from the Comunidad Autónoma de Madrid, and C.F.-M. is a doctoral fellow from the MCYT (Spain). We are grateful to Dr. Ron McKay (National Institutes of Health, Bethesda, MD) for continuous encouragement, and Dr. Enrique J. de la Rosa [Centro de Investigaciones Biológicas (CIB), Consejo Superior de Investigaciones Científicas (CSIC), Madrid] for comments throughout the work and critica reading of this manuscript. We thank Dr. José G. Pichel and Dr. Catalina Hernández-Sánchez (CIB, CSIC, Madrid) for technical support in pilot experiments.

Correspondence should be addressed to Carlos Vicario-Abejón, Centro de Investigaciones Biológicas, CSIC, Velázquez 144, E-28006 Madrid, Spain. E-mail: cvicario@cib.csic.es.

Copyright $\odot 2003$ Society for Neuroscience $\quad 0270-6474 / 03 / 230895-12 \$ 15.00 / 0$
}

ously that insulin and proinsulin [the term "(pro)insulin" will be used when referring to both proteins at once] prevent the natural cell death of retinal neuroepithelial cells (de la Rosa and De Pablo, 2000; Díaz et al., 2000). IGF-I and its receptor (IGF-IR), as well as the insulin receptor (InsR), are expressed in many regions from early stages of rodent brain development, including the olfactory bulb (OB), subventricular zone (SVZ), and hippocampus (De Pablo and de la Rosa, 1995). IGF-I is required for fibroblast growth factor-2 (FGF-2) promotion of proliferation and survival of neuroepithelial cells in vitro (Drago et al., 1991); furthermore, IGF-I is needed for epidermal growth factor (EGF) and FGF-2 induction of sphere formation in striatal stem cell cultures (Arsenijevic et al., 2001). This factor is implicated in the differentiation of neurons generated from striatal or SVZ stem cells in culture (Arsenijevic and Weiss, 1998; Brooker et al., 2000). Analysis of $I g f-I^{-1-}$ mice revealed deficits in numbers of specific neurons and oligodendrocytes in the adult $\mathrm{OB}$, dentate gyrus, and striatum (Liu et al., 1993; Beck et al., 1995; Cheng et al., 1998) and in postnatal day 20 cochlear ganglion neurons (Camarero et al., 2001). It is not known, however, whether these anatomical defects are a consequence of alterations in proliferation, survival, or differentiation caused by the absence of IGF-I during development. In addition, the role of IGF-I and (pro)insulin on putative embryonic OB stem cells is unknown. 
Neurogenesis in the OB is not completed at the end of the embryonic period but continues during postnatal life throughout adulthood (Hinds, 1968a; Luskin, 1993; Kornack and Rakic, 2001). Stem cells located in the ependymal and SVZ give rise to OB interneurons (Chiasson et al., 1999; Doetsch et al., 1999; Johansson et al., 1999; Rietze et al., 2001; Capela and Temple, 2002). In addition, stem cells resident in the adult $\mathrm{OB}$ have recently been isolated (Pagano et al., 2000; Gritti et al., 2002). The vast majority of $\mathrm{OB}$ projecting neurons arise early in embryonic development, however, before the SVZ is formed (Hinds, 1968a,b), but stem cells have not been described in the embryonic OB (Temple, 2001).

Here we analyzed whether the embryonic $\mathrm{OB}$ itself harbors stem cells and whether their proliferation, survival, and differentiation are regulated by IGF-I and (pro)insulin. We present evidence supporting the existence of stem cells born within the embryonic OB neuroepithelium that depend on IGF-I or (pro)insulin for proliferation in culture. The analysis of wild-type and Igf- $I^{-1-}$ mouse $\mathrm{OB}$ cultured cells and in vivo development indicates that endogenous IGF-I is not absolutely required for stem cell proliferation, but that it is an essential factor regulating $\mathrm{OB}$ stem and precursor cell differentiation.

\section{Materials and Methods}

Cell cultures. Reagents for tissue culture were purchased from Invitrogen (Carlsbad, CA), Sigma (St. Louis, MO), and Worthington (Freehold, NJ). IGF-I and EGF were purchased from PeproTech (Rocky Hill, NJ); FGF-2 and brain-derived neurotrophic factor (BDNF) were from R\&D Systems (Minneapolis, MN) or PeproTech; proinsulin and insulin were a kind gift from Eli Lilly (Indianapolis, IN).

Neural stem cells were prepared from CD1 mouse embryonic olfactory bulb on the gestational days (E) 12.5, E13.5, and E14.5 (the day on which a vaginal plug was found was considered E0.5). Animals were cared for in accordance with Consejo Superior de Investigaciones Científicas (CSIC) guidelines. After taking the brain out of the skull, the olfactory bulbs were dissected at the level marked in Figure $1 \mathrm{~A}$ (the image shows an E14.5 mouse brain). Note that the E13.5 OB, although smaller than the E14.5, is similar in appearance. At E12.5, however, the mouse OB is basically a primordium or anlage. Cells were obtained by mechanical dissociation of dissected and pooled olfactory bulbs, followed by mild trypsinization or mechanical dissociation only. After trypsin inhibition with 10\% FBS (heat inactivated), cells were resuspended in DMEM/nutrient mixture F12 (F12)/insulin, apotransferrin, putrescine, progesterone, and sodium selenite (N2), plated on uncoated tissue culture dishes at a density of 35,000 cells per square centimeter, and incubated at $37^{\circ} \mathrm{C}$ in a $5 \% \mathrm{CO}_{2}$ atmosphere. FGF- 2 and $\mathrm{EGF}(20 \mathrm{ng} / \mathrm{ml}$ each $)$ were added daily to expand the proliferative precursor cell population. Cells growing as floating aggregates or "spheres" (Reynolds and Weiss, 1996) were passaged every $3-5 \mathrm{~d}$ by mechanical procedures and plated at 5000 cells per square centimeter during passages.

For cell proliferation assays, cells were plated at 5000-6000 cells per square centimeter onto polyornithine-coated four-well chamber slides and cultured for 3-4 d alone or in the presence of growth factors at various concentrations. Cells were pulsed with $5 \mu \mathrm{M} 5^{\prime}$-bromo-2deoxyuridine (BrdU) (Boehringer Mannheim, Mannheim, Germany) for $20-22 \mathrm{hr}$ before fixation. To initiate olfactory bulb stem cell (OBSC) differentiation, FGF-2 and EGF were removed after the corresponding passage and cells were plated for $1-6 \mathrm{~d}$ on four-well chamber slides or glass coverslips coated with $15 \mu \mathrm{g} / \mathrm{ml}$ polyornithine and $1 \mu \mathrm{g} / \mathrm{ml} \mathrm{fi-}$ bronectin in DMEM/F12/N2 at a density of 100,000 cells per square centimeter. The cells were then fixed. In some experiments, IGF-I, insulin, or BDNF was added at various concentrations. To determine whether dividing cells could differentiate to neurons, astrocytes, and oligodendrocytes, cultures were pulsed with BrdU at a final concentration of $5 \mu \mathrm{M}$ for 22-24 hr before passage. After removal of FGF-2 and EGF, cells were cultured for 3-5 $\mathrm{d}$ and then fixed.

To test the effects of IGF-I on sphere formation, cells were passaged and then plated at 6000 cells per square centimeter into 24 -well plates, in the presence of FGF plus EGF or FGF plus EGF plus IGF-I, under insulinfree conditions. After $3 \mathrm{~d}$, cell aggregates containing six or more cells were considered to be spheres and were counted. Spheres were then left to grow up to $7 \mathrm{~d}$ for further analysis.

For clonal analysis experiments, E14.5-derived primary cell spheres from passages 4, 5, 7, 9, and 16 were dissociated mechanically, and $200 \mu \mathrm{l}$ of a cell suspension containing two cells in $200 \mu \mathrm{l}$ of DMEM/F12/N2olfactory bulb stem cell-conditioned medium (1:1) were plated into each well of 96-well plates. The next day, wells containing a single cell were marked. Cells were maintained in FGF-2 and EGF for an additional 7-10 $d$, when the marked wells were scored for the presence of primary spheres derived from a single cell. The clonally derived secondary spheres were then transferred to polyornithine-coated glass coverslips, maintained for $2 \mathrm{~d}$ in FGF-2 plus EGF, and then induced to differentiate by removal of mitogens and addition of $0.4 \%$ FBS. Cells were fixed 7-10 d after initiation of the differentiation protocol and then triple immunostained. To perform subclonal analysis, a subset of secondary spheres were dissociated mechanically, and the cells were plated and cultured as above. Olfactory bulb stem cell-conditioned medium was collected after cell centrifugation. The medium was adjusted to $\mathrm{pH} 7.15$, filtered, and stored at $-80^{\circ} \mathrm{C}$.

Cell culture and genotype determination of IGF-I knock-out mice. Cells suspensions were prepared individually from each embryo at day E14.5 of gestation from female $I g f-I^{+/-}$mice mated with male $I g f-I^{+/-}$mice, targeted, and kindly donated by Dr. A. Efstratiadis (Columbia University, New York, NY). Single-cell suspensions from the two olfactory bulbs of each embryo were prepared by mechanical procedures, plated in uncoated eight-well chamber slides, and incubated in DMEM/F12/N2 plus FGF-2 and EGF and insulin, as described above. Cells were expanded, passaged, and induced to differentiate, in the absence of insulin, at various times during the culture period, or incubated with $5 \mu \mathrm{M}$ BrdU for proliferation assays, as described above.

Embryo genotypes were determined by Southern blotting. DNA was obtained by standard methods from the tail or extremities of each embryo. The hybridization probe was a $450 \mathrm{bp} \mathrm{HindIII-XbaI} \mathrm{fragment} \mathrm{lo-}$ cated upstream of exon 4 of the Igf-I gene (Liu et al., 1993). The bands generated after genomic DNA digestion with HincII and BglI were 6 and $7 \mathrm{kbp}$ for wild type and mutant $I g f-I$, respectively. Only cultures from $I g f-I^{-1-}$ and $I g f-\mathrm{I}^{+/+}$embryos were analyzed.

Immunostaining of cultured cells. Cultured cells were fixed with $4 \%$ paraformaldehyde/0.1 M phosphate buffer, $\mathrm{pH} 7.4$, for $25 \mathrm{~min}$. Cultures incubated with BrdU were fixed with $4 \%$ paraformaldehyde/ $0.1 \mathrm{~m}$ borate $\left(\mathrm{Na}_{2} \mathrm{~B}_{4} \mathrm{O}_{7}\right.$ ) buffer, $\mathrm{pH} 9.5$, for $25 \mathrm{~min}$, treated with $2 \mathrm{~N} \mathrm{HCl}$ for $10 \mathrm{~min}$, and neutralized in $0.1 \mathrm{M} \mathrm{Na}_{2} \mathrm{~B}_{4} \mathrm{O}_{7}$ for $10 \mathrm{~min}$. After treatment with $0.1 \%$ Triton X-100/10\% normal serum/PBS (Triton was avoided for some antigens), cells were incubated overnight at $4^{\circ} \mathrm{C}$ with primary antibodies against nestin (rabbit polyclonal, 1:1000; a kind gift of Dr. R. McKay, National Institutes of Health, Bethesda, MD), BrdU [mouse monoclonal, $1: 20$, from Becton Dickinson (San Jose, CA), or the Developmental Studies Hybridoma Bank, 1:1000-1:2000], $\beta$-III-tubulin [TuJ1, mouse monoclonal, 1:200, from Sigma or rabbit polyclonal, 1:2000-1:4000 from Babco (Richmond, CA)], MAP-2ab (mouse monoclonal, 1:200, from Sigma), GFAP [rabbit polyclonal, 1:1000 from Dako (Glostrup, Denmark), or mouse monoclonal, 1:300, Sigma], O4 (mouse monoclonal IgM, 1:8, kindly shared by Dr. A. Rodríguez Peña, Instituto de Investigaciones Biomédicas, Madrid), calretinin [rabbit polyclonal, 1:1500, from Swant (Bellinzona, Switzerland)], GABA (rabbit polyclonal, 1:1000, from Sigma), IGF-I (rabbit polyclonal, 1:500 from National Institute of Diabetes and Digestive and Kidney Diseases National Hormone and Peptide Program and A. F. Parlow), IGF-IR [IC469, rabbit polyclonal, 1:50, a kind gift of Dr. R. Garofalo (Pfizer, Groton, CT)], InsR (pp5, rabbit polyclonal, 1:300, a gift of Dr. R. Garofalo), and (pro)insulin (guinea pig polyclonal, lot 627, 1:500, Department of Pharmacology, Indiana University, Indianapolis, IN). Cells were then incubated with the corresponding fluorescein, rhodamine, Texas Red, and/or Alexa fluor 350-conjugated secondary antibodies (1:100) (Jackson ImmunoResearch, West Grove, PA; Cappel, Durham, NC; Molecular Probes, Eugene, OR) or with a biotinylated secondary antibody (1:200) followed 
by avidin-biotin-horseradish peroxidase complex (Vectastain ABC kit, Vector, Burlingame, CA) and developed using 3,3'-diaminobenzidine (DAB; Sigma) and $\mathrm{H}_{2} \mathrm{O}_{2}$. Coverslips were mounted in 1,4 diazabicyclo (2.2.2) octane/glycerol. Controls were performed to confirm primary and secondary antibody specificity. Some cultures were stained with 2 $\mu \mathrm{g} / \mathrm{ml} \mathrm{4}^{\prime}$,6-diamino-2-phenylindole to allow accurate cell counting. The anti-BrdU monoclonal antibody (G3G4) developed by S. J. Kaufman was obtained from the Developmental Studies Hybridoma Bank maintained by The University of Iowa, Department of Biological Sciences, Iowa City, IA.

Immunostaining of anatomical sections from Igf-I $I^{-/-}$and $I g f-I^{+/+}$ mice. The histological study was performed in two different mouse colonies. The first Igf-I-targeted colony was that from which cell cultures were prepared (see above). A second colony was the result of crossing mice from the first colony with mice carrying a deletion in the leukemia inhibitory factor ( Lif) gene (kindly donated by Dr. C. L. Stewart, National Cancer Institute, Frederick, MD) and was established in our laboratory to study possible coordinated actions between IGF-I and LIF in organ development (Pichel et al., 2003). In both colonies, the OB phenotype was similar and attributable specifically to the lack of both Igf-I alleles. For histology, paraffin $(7 \mu \mathrm{m})$ and cryostat $(15 \mu \mathrm{m})$ sections were prepared. Heads were fixed in $4 \%$ paraformaldehyde in PBS, decalcified in 0.3 м EDTA, pH 6.3, dehydrated in ethanol, and paraffin embedded. To prepare cryostat sections, fixed brains were immersed in $30 \%$ sucrose for $24-48 \mathrm{hr}$ and then frozen at $-70^{\circ} \mathrm{C}$ in dry ice. Sections were stained with hematoxylin/eosin (H\&E) or cresyl violet or were immunostained. For the latter, paraffin sections were dewaxed and rehydrated; paraffin and air-dried cryostat sections were incubated with $7.4 \% \mathrm{H}_{2} \mathrm{O}_{2}$ for $10 \mathrm{~min}$ and exposed to a solution of $0.2-0.3 \%$ Triton X-100 and $1-10 \%$ goat or horse serum in PBS for $1 \mathrm{hr}$. They were incubated overnight at $4^{\circ} \mathrm{C}$ or at room temperature with the polyclonal primary antibodies anti-nestin (1:1000), anti-calretinin (1:1500), and anti-neurotensin (1:1000; kindly provided by Prof. R. Coveñas, University of Salamanca, Salamanca, Spain). After washes, sections were incubated for $1 \mathrm{hr}$ at room temperature with biotinylated anti-rabbit IgG (1:200). The Vectastain ABC kit was used, and peroxidase activity was developed using DAB and $\mathrm{H}_{2} \mathrm{O}_{2}$. Finally, the sections were dehydrated and coverslipped with Permount.

Sphere and cell counts and statistical analysis. To determine the number of spheres, a total of 10 random fields per well were counted using a $10 \times$ objective in an inverted microscope. To determine the number of cells expressing a specific antigen, a total of 10 random fields per chamber or coverslip were counted using a 20 or $40 \times$ objective under fluorescence filters or bright-field optics (Zeiss Axioplan microscope). Results are expressed as the number of cells stained for that antigen in 10 fields. The total, stained plus nonstained, number of cells was counted to calculate the proportion of a particular cell type in the culture. Results are the average \pm SEM of data from four to eight cultures of three to six experiments, unless stated otherwise. Cultures from different passages were analyzed (see legends to the figures). Results from the Igf-I $I^{-1-}$ and Igf $-I^{+/+}$cultures are the average \pm SEM of data from $6-12$ cultures of three to six embryos. Statistical analyses were performed using Student's $t$ test.

\section{Results \\ Isolation and characterization of stem cells from the E12.5-E14.5 olfactory bulb}

To isolate local olfactory bulb stem cells, a cell suspension was prepared from mouse E14.5 OB (Fig. $1 A$ ) and plated under tissue culture conditions in the presence of FGF-2 plus EGF and insulin. One day after plating, many cells in the culture had immature neuronal morphology (Fig. $1 \mathrm{~B}$, arrowheads) bearing several neurites. A smaller proportion of the cells showed a rounded morphology (arrows). Daily visualization of the cultures indicated that the rounded cells divided, forming cell aggregates or spheres (Reynolds and Weiss, 1996) (Fig. 1B) that grow to confluence in the presence of the mitogens by day 4 (Fig. $1 D, E$ ). Because rostral migration of SVZ-derived proliferative neuroblasts to the mouse OB may occur from E14.5 but not at earlier ages (Hinds, 1968b), cell suspensions were also prepared from the E13.5 and E12.5 OB.
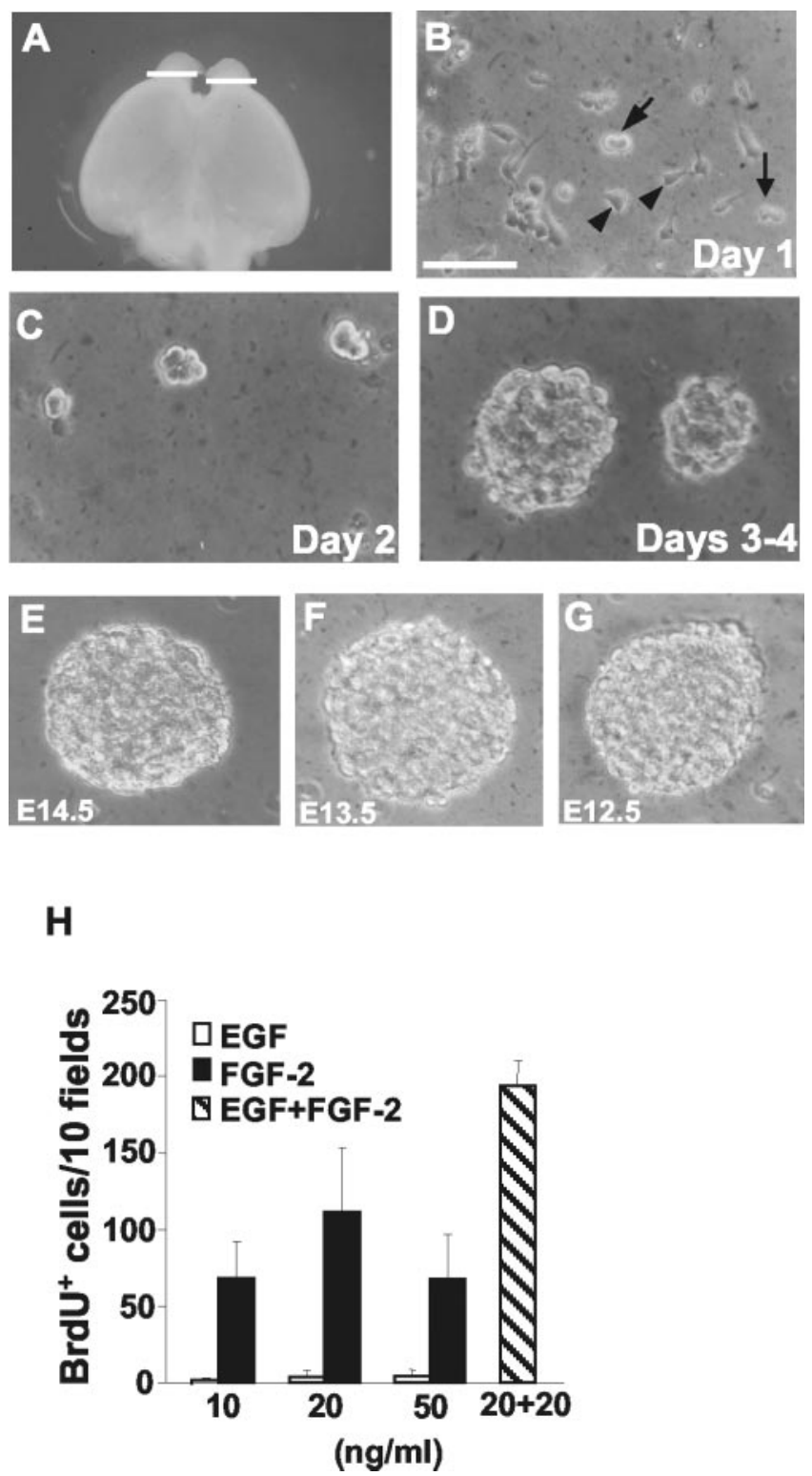

Figure 1. Cells that respond to FGF-2 plus EGF by proliferating and forming spheres can be isolated from the embryonic olfactory bulb. Cells prepared from the $\mathrm{OB}$ of E12.5, E13.5, and E14.5 mice were plated in the presence of $20 \mathrm{ng} / \mathrm{ml} \mathrm{FGF-2,20} \mathrm{ng/mI} \mathrm{EGF,} \mathrm{and} 10 \mu \mathrm{g} / \mathrm{ml}$ insulin. $A$, Dorsal view of a E14.5 mouse brain. The lines mark the plane of the $O B$ dissection. $B, 0$ ne day after plating, some cells with rounded morphology (arrows) were surrounded by cells with immature neuronal morphology (arrowheads). C, Day 2, the rounded cells divided and formed small aggregates or spheres, which detached from the bottom of the plate and floated. $D, E$, Days 3-5, the spheres increased in size as a result of additional cell division and aggregation. $F$, $G$, Large spheres were also obtained from E13.5 $(F)$ and E12.5 $(G)$ cell cultures at days 4-5. There were small variations between cultures in the timing of sphere formation. $H$, Effect of various concentrations of FGF-2 and EGF, or FGF-2 plus EGF, on BrdU incorporation by E14.5 OB precursor cells. Results are the mean \pm SEM of data from four cultures. Scale bar, $40 \mu \mathrm{m}$.

After plating, the E13.5- and E12.5-derived cells proliferated and formed spheres in response to FGF-2 plus EGF, with the same temporal pattern as the E14.5 OB-derived cultures (Fig. $1 F, G$ ). During the first days after the original cell suspension was plated, FGF-2 but not EGF promoted cell proliferation, although the combination of both factors gave the maximum number of BrdU-positive cells (Fig. $1 H$ ). After passages 1-2, cells could be grown in either factor alone, but the yield of proliferative cells was still greater when both factors were added together (data not 
shown). These results support the concept that FGF-2-responsive stem cells are born early in embryonic development and that they give rise to EGF-responding stem cells at later stages (Ciccolini and Svendsen, 1998; Tropepe et al., 2001).

Under these standard growth conditions, cells could be passaged every $3-5 \mathrm{~d}$ for at least 5.5 months ( 40 passages), representing $\sim 150$ cell doublings (Fig. $2 A$ ). The average doubling time of these cells was approximately $26 \mathrm{hr}$. The $\mathrm{x}$-fold increase in cell number varied between passages, but no tendency was observed toward lower numbers in the last passages. If all cells had been passaged, a theoretical estimation of the total yield of nestinpositive cells resulted in $10^{25}$ cells at 3 months and $10^{45}$ at 5.5 months. Cell proliferation required FGF-2 plus EGF even after long periods in culture, indicating that they were not transformed into growth factor-independent cells (data not shown). In cultures growing in the presence of FGF-2 plus EGF and insulin for up to 3 months (passage 23), 99.2\% of cells expressed nestin (Fig. $2 B, C)$, a marker of neuroepithelial cells, and $<0.1 \%$ expressed antigen markers for neurons ( $\beta$-III-tubulin), astrocytes (GFAP), or oligodendrocytes $(\mathrm{O} 4)$ [for references on cell markers, see Vicario-Abejón et al. (1995) and Johe et al. (1996)]. On average, $86.5 \%$ of cells incorporated BrdU (Fig. $2 B, D$ ); this value was $96.2 \%$ at passage $15,81.1 \%$ at passage 23 , and $77.6 \%$ at passage 36 (Fig. 2 B, inset). Similarly, E12.5 and E13.5 cultures proliferated extensively: they were composed of $99.5-100 \%$ nestin-positive cells, whereas $\leq 0.4 \%$ of the cells were positive for neuronal or glial markers. Together, these results indicate that $\mathrm{OB}$ cultures were composed predominantly of highly proliferative neural precursor cells that could be expanded for long periods of time. In addition, the near absence of $\beta$-III-tubulin-positive immunostaining, a marker of SVZ-derived migrating neuroblasts (Menezes and Luskin, 1994), and of GFAP-positive immunostaining, a marker of adult SVZ stem cells (Doetsch et al., 1999) in the cultures, further supports the conclusion that the source of the proliferative precursors is the OB neuroepithelium and not the SVZrostral migratory stream (RMS).

To test whether these proliferative precursor cells had stem cell features (multipotentiality and self-renewal capacity) (Anderson, 2001; Temple, 2001), clonal analysis experiments were performed (Fig. 3; Table 1). Two hundred microliters of a E14.5-derived cell suspension containing two cells obtained from primary spheres (passages 4-16) were plated in 96 wells; the next day, $22.2 \pm 2.5 \%$ ( $n=5$ experiments) of the wells contained a single cell. Only those wells were fed with FGF-2 plus EGF and maintained for further analysis. After $7-10 \mathrm{~d}, 42.5 \pm 4.6 \%(n=5$ experiments $)$ of the single cells formed spheres. Twelve clonally derived secondary spheres and six clonally derived tertiary spheres were analyzed by triple immunostaining. Of the spheres, $61.1 \%$ generated neurons, astrocytes, and oligodendrocytes after differentiation, indicating that the founder cells were multipotent (Fig. 3, Table 1). Other clonally derived spheres gave rise to neurons and astrocytes (5.6\%), astrocytes and oligodendrocytes $(5.6 \%)$, neurons $(5.6 \%)$, or astrocytes only $(22.2 \%)$. Dissociation and subclonal analysis of clonally derived secondary spheres confirmed the presence of cells that were multipotent with self-renewal capacity. In fact, four of six tertiary spheres gave rise to neurons, astrocytes, and oligodendrocytes.

Olfactory bulb stem cells express IGF-I, (pro)insulin, and their cognate receptors, and these factors cooperate with FGF-2 plus EGF to promote proliferation

Expression of IGF-I, (pro)insulin, the IGF-IR, and the InsR was detected in the majority of OBSCs using previously characterized antibodies (Fig. 2E-H) (Herrera et al., 1985; Quiroga et al., 1995;
A

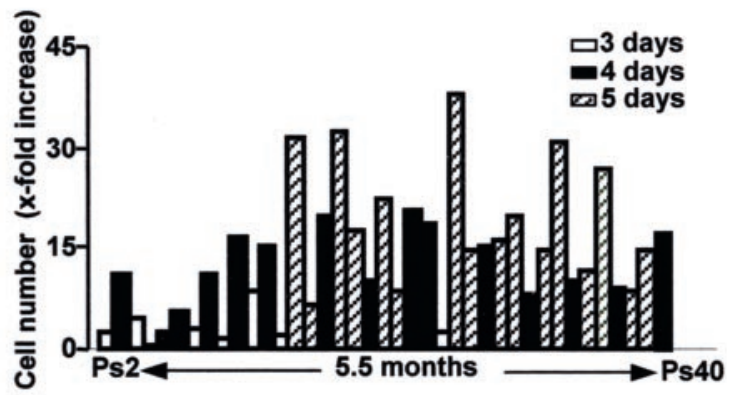

B
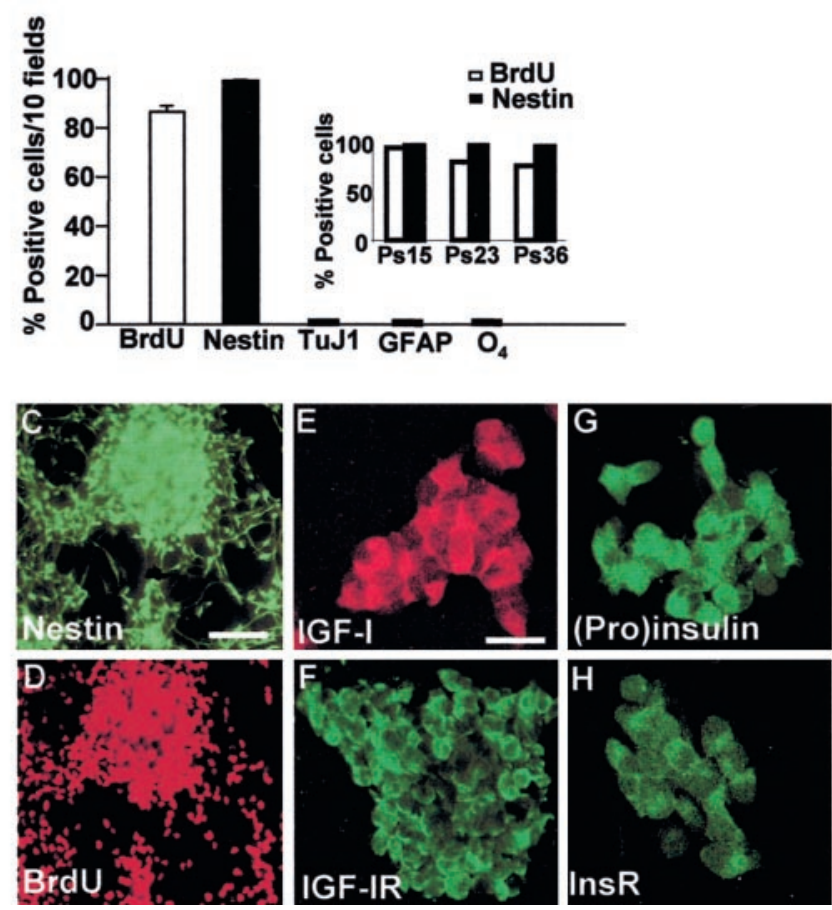

Figure 2. Antigen expression and BrdU labeling of expanded olfactory bulb stem cells. E14.5-derived cells were plated in the presence of FGF- 2 and EGF ( $20 \mathrm{ng} / \mathrm{ml}$ each) and $10 \mu \mathrm{g} / \mathrm{ml}$ insulin; $5 \mu \mathrm{m}$ BrdU was added to some cultures. $A$, The $x$-fold increase in cell number in each passage from 2 to 40 was measured by Trypan blue dye exclusion. Cells were passaged every $3-5 \mathrm{~d}$. Other cultures were maintained to passage $20-23$; their growth pattern was similar to the example shown. $B$, Antigen expression and BrdU labeling in OBSCs at different passages. In the main graph, for each cell marker, results show the mean \pm SEM of data from five cultures of four experiments (passages 3, 4, 15, and 23). Inset, Results are the mean of data from two cultures analyzed at the passages (Ps) indicated. $(-H$, Images showing nestin, BrdU, IGF-I, IGF-IR, (pro)insulin, and InsR expression by OBSCs. IGF-I, (pro)insulin, and InsR immunostainings were performed on fixed cells that had been cultured previously for $3 \mathrm{~d}$ in the absence of IGF-I and insulin in the medium. Cultures were photographed under a fluorescence microscope $(C, D)$, or images were captured using a confocal microscope $(E-H)$. Scale bars: $C, D, 19 \mu \mathrm{m} ; E$, $G, H, 6 \mu \mathrm{m} ; F, 10 \mu \mathrm{m}$.

Alarcón et al., 1998; Díaz et al., 2000). On average (mean of two experiments), IGF-I and (pro)insulin were expressed in 99.8 and $96.5 \%$ of cells, respectively. IGF-IR was expressed in $89.2 \pm 4.4 \%$ $(n=3)$ and InsR in $97.3 \pm 0.9 \%(n=3)$ of cells. Specific RT-PCR for proinsulin I and II showed that the mRNA expressed by stem cells was proinsulin II (C. Hernández-Sánchez, M. J. Yusta-Boyo, C. Vicario-Abejón, F. de Pablo, unpublished observations). We thus tested the action of exogenous IGF-I, insulin, and proinsulin alone or in combination with FGF-2 plus EGF on the proliferation and survival of OBSCs, growing at low density (5000-6000 


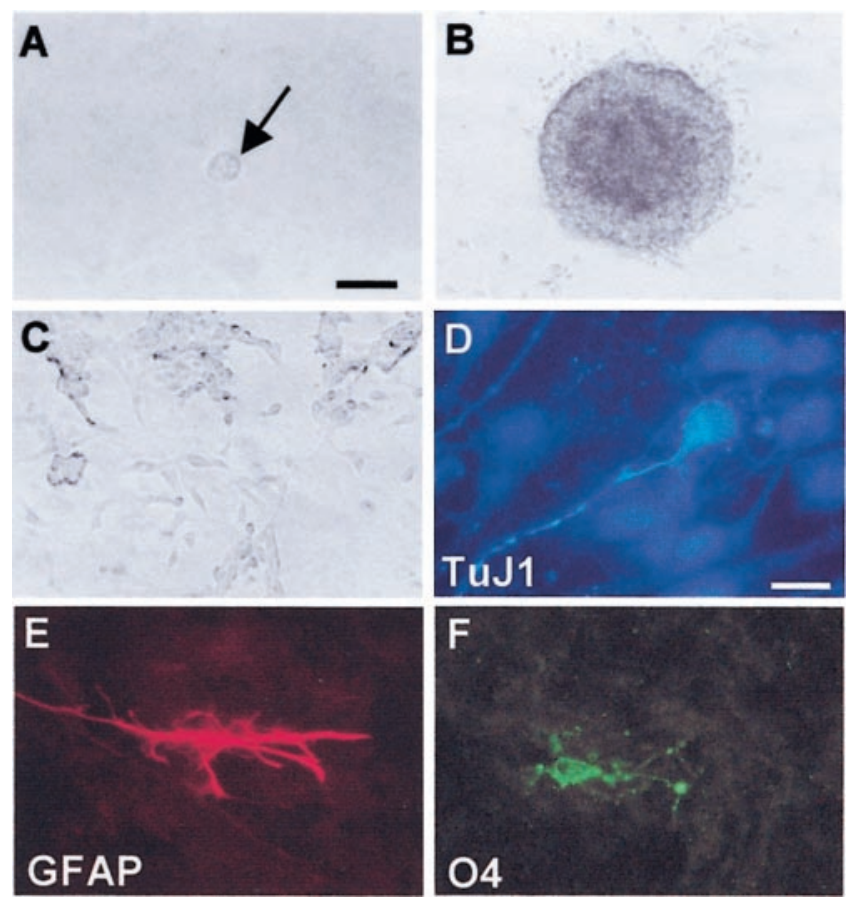

Figure 3. Neurons, astrocytes, and oligodendrocytes can be derived from single-plated E14.5 olfactory bulb precursor cells. A cell suspension containing two cells in $200 \mu \mathrm{l}$ of DMEM/ F12/N2-OBSC conditioned medium (1:1) was plated into each well of 96 -well plates. $A$, Wells containing only a single cell were marked. $B$, Clonally derived spheres were then transferred to polyornithine-coated glass coverslips, maintained for $2 \mathrm{~d}$ in FGF-2 plus EGF, and then $(C)$ induced to differentiate. Cells were fixed $7-10 \mathrm{~d}$ after and triple immunostained using antibodies against neurons (D, TuJ1), astrocytes (E, GFAP), and oligodendrocytes $(F, 04)$. Scale bars: $A, C$, $8.5 \mu \mathrm{m} ; B, 17 \mu \mathrm{m} ; D-F, 6 \mu \mathrm{m}$.

cells per square centimeter, proliferative conditions). Proinsulin and insulin alone were ineffective in promoting the proliferation of olfactory bulb cells and had only a minimal effect on cell survival, even when high concentrations of these proteins were added to the cultures (Fig. 4; Table 2). In contrast, $100 \mathrm{ng} / \mathrm{ml}$ IGF-I elicited a significant increase both in the total number and in the number of proliferative cells, compared with values obtained with insulin or proinsulin. In the IGF-I-treated cultures, however, only $33.2 \%$ of cells were BrdU positive (Table 2), and some cells expressed neuronal or glial markers (data not shown). Similar results were obtained in the IGF-I plus insulin-treated cultures. In the absence of (pro)insulin or IGF-I, FGF-2 plus EGF promoted cell proliferation to a suboptimal level (Fig. 4, Table 2). The classical stem cell mitogens, FGF-2 and EGF alone, were thus insufficient to induce optimal cell proliferation rates, and under these conditions, maintenance and expansion of the cells were inefficient and variable.

We then tested whether the insulin-related growth factors cooperated with FGF-2 plus EGF to promote OBSC proliferation. As shown (Fig. $4 A, B$ ), either $100 \mathrm{ng} / \mathrm{ml}$ insulin or IGF-I or proinsulin in addition to FGF-2 plus EGF yielded significantly higher

Table 1. Clonal analysis of olfactory bulb expanded proliferative precursor cells

\begin{tabular}{|c|c|c|c|c|c|}
\hline & \multicolumn{5}{|c|}{ Cell types } \\
\hline & NAO & NA & A0 & $\mathrm{N}$ & A \\
\hline Clones (\%) & 61.1 & 5.6 & 5.6 & 5.6 & 22.2 \\
\hline
\end{tabular}

Cells were cultured, fixed, and immunostained as described in Materials and Methods and the legend to Figure 3. A total of 18 clonally derived secondary (12) and tertiary (6) spheres were analyzed. N, Neurons (TuJ1+); A, astrocytes $($ GFAP +$)$; 0 , oligodendrocytes $(04+)$.
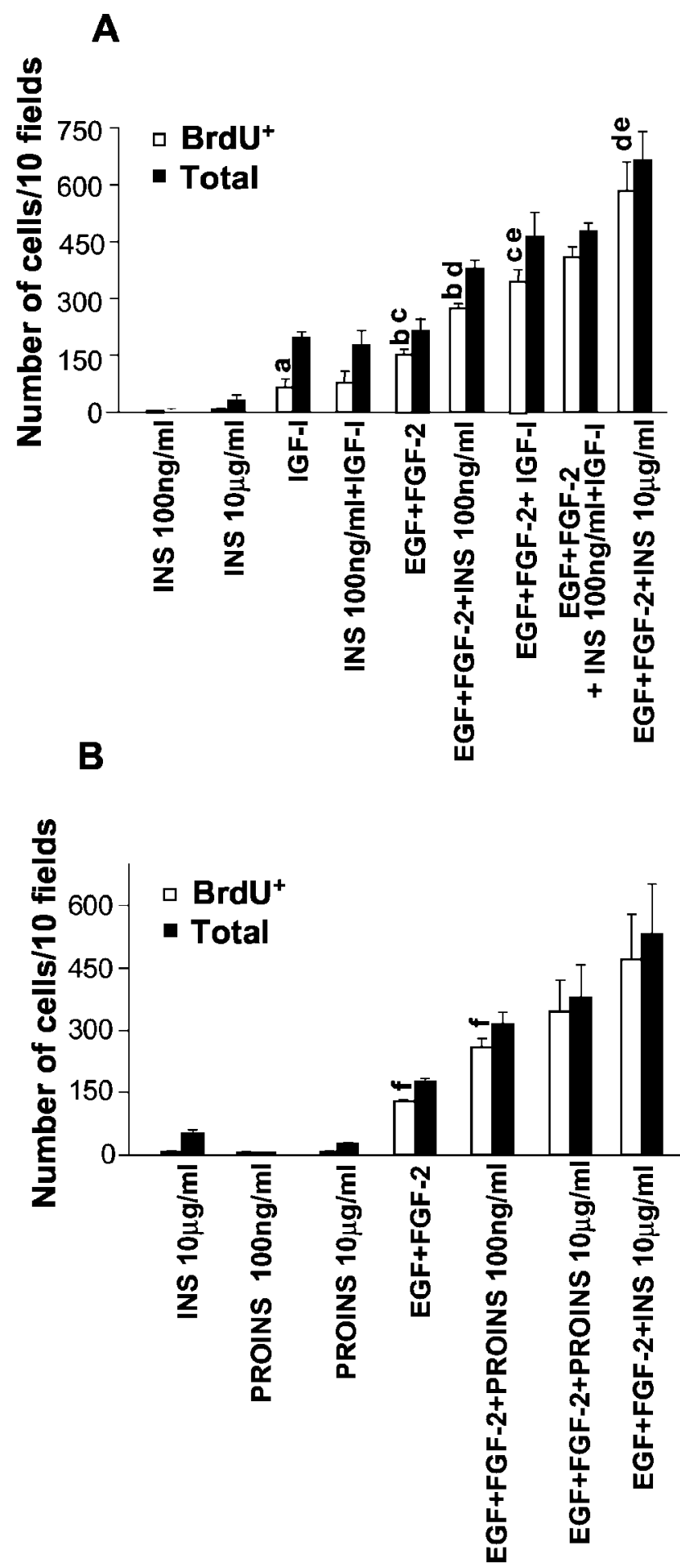

Figure 4. Effect of IGF-I, insulin, and proinsulin on olfactory bulb precursor cell proliferation. E14.5-derived cells growing in medium containing FGF-2 plus EGF and $10 \mu \mathrm{g} / \mathrm{ml}$ insulin were passaged mechanically and plated in four-well chamber slides, where they were maintained for 3-4 $\mathrm{d}$ in the presence of the indicated growth factor concentration. $A$, Effect of insulin (INS), IGF-I, FGF-2, and EGF or their combinations on BrdU incorporation and total cell number. $B$, Effects of proinsulin (PROINS) compared with insulin, FGF-2, and EGF or their combinations on BrdU incorporation and total cell number. The concentration of FGF- 2 and EGF was always $20 \mathrm{ng} / \mathrm{ml}$. The concentration of IGF-I was always $100 \mathrm{ng} / \mathrm{ml}$. Letters $(a-f)$ indicate statistically significant changes $(p<0.05)$ between the two values compared, using Student's $t$ test. Results are the mean \pm SEM of data from four cultures of two experiments (passage 3). 
Table 2. Percentages of BrdU-positive cells in cultures of olfactory bulb precursor cells

\begin{tabular}{lllll}
\hline INS $_{\mathrm{h}}$ & IGF-I & FGF-2 + EGF & $\begin{array}{l}\text { FGF-2 + EGF } \\
+ \text { IGF-I + INS }\end{array}$ & $\begin{array}{l}\text { FGF-2 + EGF } \\
+ \text { INS }_{\mathrm{h}}\end{array}$ \\
\hline $5.3 \%$ & $33.2 \%$ & $70.4 \%$ & $85.9 \%$ & $87.7 \%$ \\
$(1.5 / 28.3)^{a}$ & $(65.0 / 195.5)^{a}$ & $(151.8 / 215.5)^{a}$ & $(409.0 / 476.3)^{a}$ & $(583.0 / 664.8)^{a}$ \\
\hline
\end{tabular}

Data were derived from results presented in Figure 4A. INS, $10 \mu \mathrm{g} / \mathrm{ml}$ insulin; INS, $100 \mathrm{ng} / \mathrm{ml}$ insulin; IGF-I, 100 $\mathrm{ng} / \mathrm{ml} ; \mathrm{FGF}-2$ and EGF, $20 \mathrm{ng} / \mathrm{ml}$. The effects of proinsulin were similar or slightly lower than those of insulin (Fig. 4B).

${ }^{a}$ Number of BrdU + cells/total cell number.

numbers (1.8- to 2.7-fold; $p<0.05)$ of dividing and total cells than FGF-2 plus EGF alone. Cooperation was additive between IGF-I and FGF-2 plus EGF, and synergistic between (pro)insulin and FGF-2 plus EGF. The proportion of BrdU-positive cells increased progressively from the FGF-2 plus EGF-treated cultures to FGF-2 plus EGF plus high insulin-treated cultures (Table 2). Additionally, because BDNF promoted survival and proliferation of SVZ precursor cells (Benraiss et al., 2001; Pencea et al., 2001), the action of this neurotrophin was tested on $\mathrm{OB}$ precursors. BDNF produced no effect on cell proliferation or survival under any assay conditions (data not shown). Maximum levels of both dividing and total cells were found when FGF-2 and EGF were added to a medium containing high insulin $(10 \mu \mathrm{g} / \mathrm{ml}$ ) (Table 2), and these were chosen as standard culture conditions for proliferation. Proinsulin $(10 \mu \mathrm{g} / \mathrm{ml})$ also stimulated proliferation in the presence of FGF-2 plus EGF but was slightly less efficient than insulin (Fig. 4B). All of these results show that exogenous insulinrelated growth factors are necessary together with FGF-2 plus EGF to promote optimal OBSC proliferation in culture.

Because BrdU can be incorporated by stem cells and other dividing progenitors, we tested whether IGF-I was necessary for sphere formation (a fact that attests to the presence of stem cells) (Arsenijevic et al., 2001). As seen in Figure 5, $A$ and $B$, the addition of IGF-I for $3 \mathrm{~d}$ to the FGF plus EGF-treated cultures allowed generation of markedly larger spheres than those generated in FGF plus EGF alone. Under the latter conditions, however, the size of the spheres increased after 5-7 d in culture (Fig. 5C). (At that point, most spheres in the IGF-I-containing cultures were very confluent; data not shown). To perform a quantitative analysis of the IGF-I effects, cell aggregates formed by at least six to eight cells were considered to be spheres and counted after $3 \mathrm{~d}$. Figure $5 D$ shows that the number of spheres was significantly higher in the IGF-I-containing cultures than in the cultures containing only FGF plus EGF, and this effect was independent of the embryonic age of the tissue. All of these results show that IGF-I is necessary for optimal sphere formation. In addition, they show that spheres can be formed in the presence of FGF plus EGF alone, although with significantly slower kinetics, as the BrdUincorporation analysis also indicated (Fig. 4).

\section{Neurons and glia generated from olfactory bulb stem cells respond differently to IGF-I: cooperation among IGF-I, insulin, and BDNF}

Our clonal analysis shows that a single proliferative cell from the olfactory bulb has the potential to give rise to three main CNS cell types: neurons, astrocytes, and oligodendrocytes (Fig. 3, Table 1). We studied the differentiation of E14.5-derived stem cells using high-density culture conditions (100,000 cells per square centimeter) and analyzed the effect of IGF-I, insulin, and BDNF on these processes. Removal of FGF-2 and EGF, although maintaining insulin, initiated OBSC differentiation into neurons (TuJ1 and/or MAP2ab-positive cells), astrocytes (GFAP-positive cells), and oligodendrocytes (O4-positive cells) (Fig. 6A), as reported
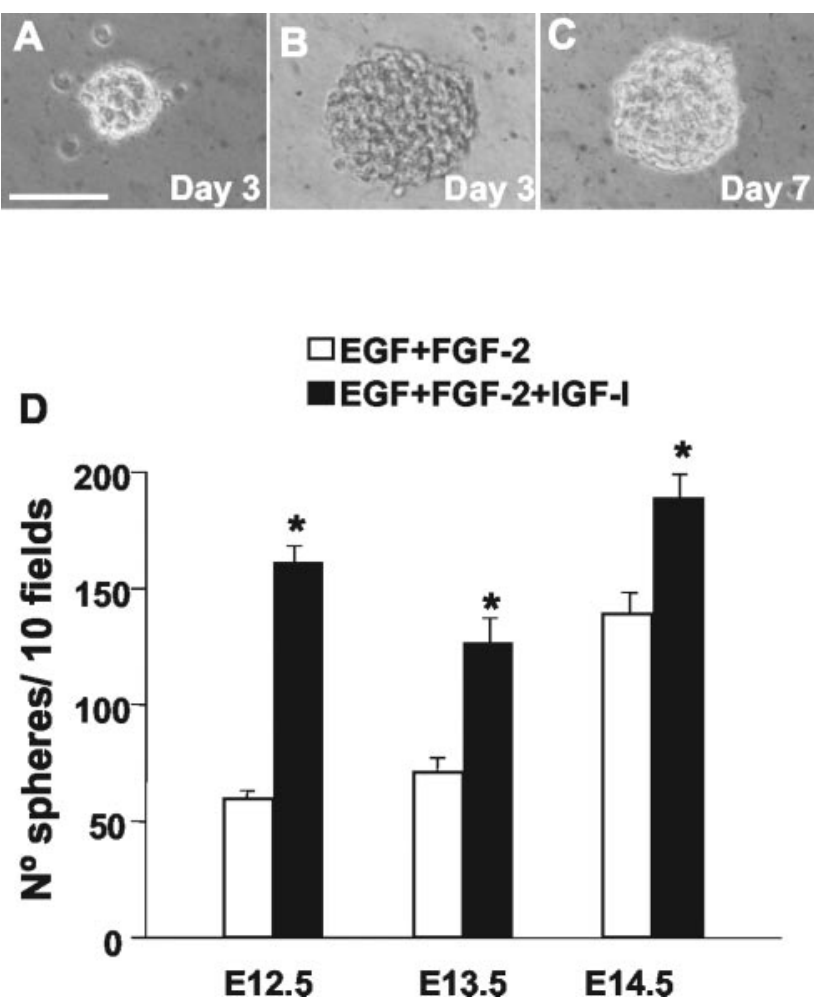

Figure 5. Effect of IGF-I on sphere formation. Cells growing in medium containing FGF-2 plus EGF and $10 \mu \mathrm{g} / \mathrm{ml}$ insulin were passaged mechanically and plated in 24-well plates in the absence of insulin, where they were maintained for $3 \mathrm{~d}(A, B, D)$ or $7 \mathrm{~d}(C)$. A, E14.5-derived sphere growing in the presence of FGF-2 plus EGF. B, E14.5-derived sphere growing in the presence of FGF-2 plus EGF plus IGF-I. C, E12.5-derived sphere growing in the presence of FGF-2 plus EGF. D, The number of E12.5-E14.5-derived spheres growing in the absence or presence of IGF-I was counted. Results are the mean \pm SEM of data from five cultures (passages 3-6). Growth factor concentrations were as in Figure 4. Scale bar, $40 \mu \mathrm{m} .{ }^{*} p<0.05$.

for hippocampal and striatal/subependymal stem cells (Gritti et al., 1996; Johe et al., 1996; Vicario-Abejón et al., 2000). The increase in TuJ1-positive cells was more pronounced during the first $2 \mathrm{~d}$ of culture, whereas the number of astrocytes augmented gradually up to day 4 . One day after mitogen withdrawal, very few oligodendrocytes could be detected in the cultures. Under these conditions, neuronal generation therefore preceded that of astrocytes and oligodendrocytes; this is consistent with the in vivo situation (Jacobson, 1991) and with previous work in culture (Qian et al., 2000). $\beta$-III-tubulin expression in neurons preceded MAP-2ab expression (Fig. 6A), a pattern reminiscent of other neuronal systems (Menezes and Luskin, 1994).

Notably, the proportion of neurons was greater than that of astrocytes and oligodendrocytes at all time points studied. The average cell percentages obtained at 3 and $4 \mathrm{~d}$ after mitogen withdrawal in the presence of insulin was 52\% neurons, $26 \%$ astrocytes, and $4 \%$ oligodendrocytes (Fig. 6B). Neuronal and glial differentiated progeny were obtained from stem cells both in early (passages $4-8)$ and late passages $(15,23,40)$ (Fig. $6 B, C)$. To show that the majority of differentiated cells had originated from dividing cells in the culture, BrdU was added to the FGF-2 plus EGF-treated cultures for $22 \mathrm{hr}$. Once differentiated and fixed, double immunostaining of cultures for $\mathrm{BrdU}$ and the neuronal or glial markers showed $87.4 \pm 1.8,82.8 \pm 2.0$, and $64.3 \pm 6.2 \%$ double BrdU-positive and TuJ1-, GFAP-, or O4-positive cells, respectively ( $n=4-5$ cultures; passages $6-23)$. In accordance with the clonal analysis experiments, these results indicate that 


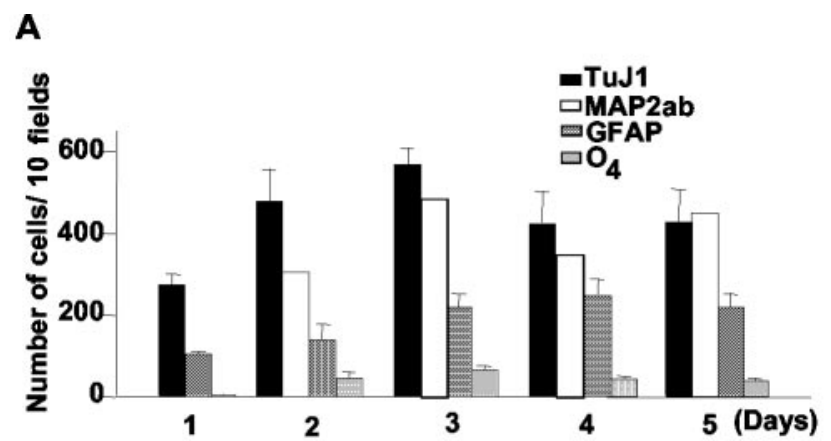

\section{B}
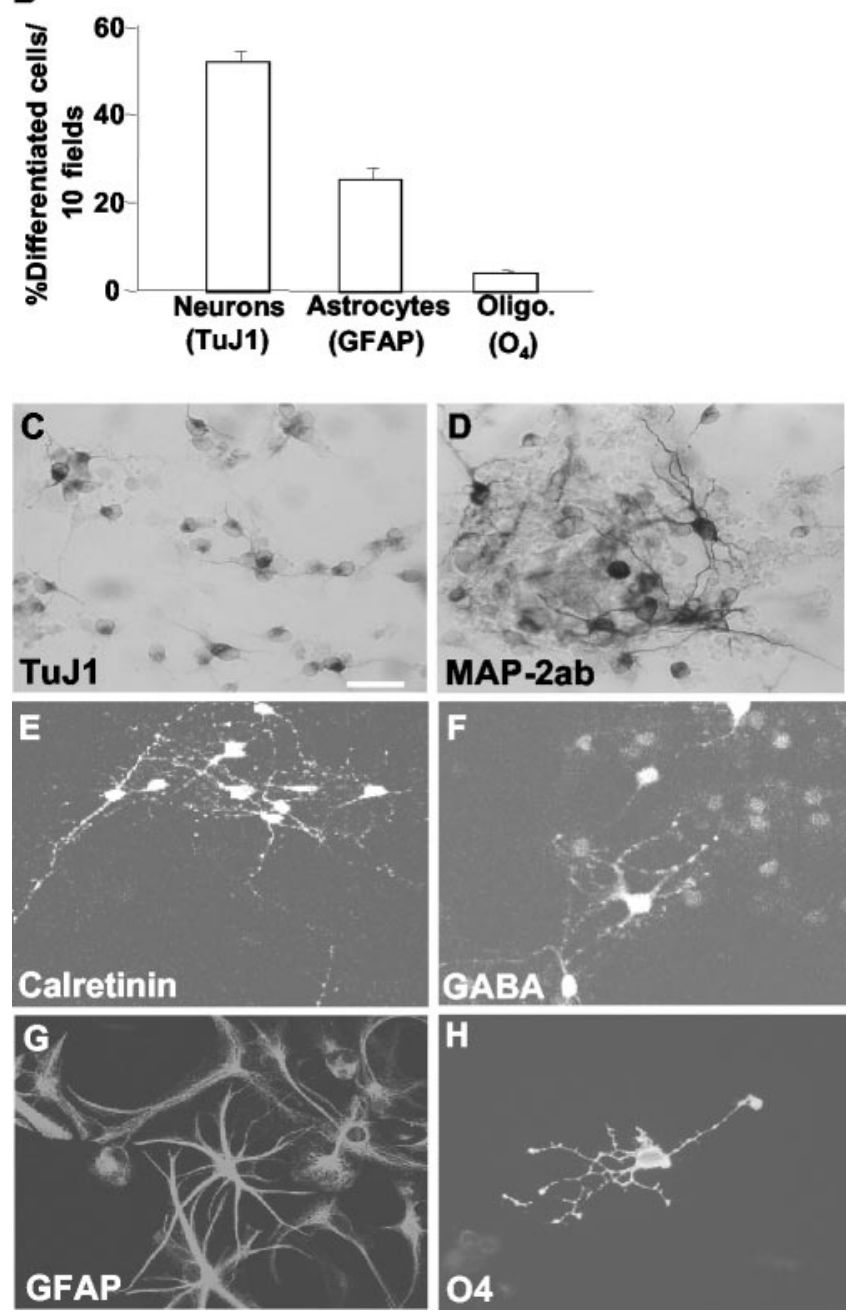

Figure 6. Olfactory bulb stem cell differentiation into neurons, astrocytes, and oligodendrocytes: time course and proportions. E14.5-derived cells cultured in FGF-2 plus EGF and insulin were passaged mechanically and plated in four-well chamber slides or glass coverslips for 3- $4 \mathrm{~d}$ in the absence of the mitogens but maintaining insulin. After fixation, cells were immunostained with the indicated antibodies. A, Time course of TuJ1-, MAP2ab-, GFAP-, and 04-positive cells generated from stem cells. Results are the mean \pm SEM of data from four to seven cultures of three experiments (passages 4 and 8 ). Numbers of MAP-2ab + cells are the mean of data from two cultures of one experiment. $B$, Average numbers of each type of cell generated from stem cells after 3-4 d of differentiation. Results are the mean \pm SEM of data from 14-15 cultures of eight experiments (passages $4-8)$. $(-H$, Morphological characteristics of neurons, astrocytes, and oligodendrocytes derived from olfactory bulb stem cells. C, TuJ1-positive cells, passage 5. D, MAP-2abpositive cells, passage 40. E, Calretinin-positive cells, passage 4. F, GABA-positive cells, passage 4. G, GFAP-positive cells, passage 40. H, 04-positive cell, passage 15. Scale bar (shown in C): C, $15 \mu \mathrm{m} ; D, 7 \mu \mathrm{m} ; E, F, 10 \mu \mathrm{m} ; G, H, 12 \mu \mathrm{m}$.
OBSCs are able to generate the major CNS cell types after proliferating for long periods of time in culture. In addition, neuronal subtypes such as calretinin-positive cells and, in lower proportion, GABA- or GAD-positive cells, were present in the cultures (Fig. 6E,F).

The above results were obtained in the presence of a high insulin concentration in the medium. We next studied the specificity of the effects of exogenous IGF-I, in the absence of insulin, during the differentiative phase of stem cells. In the absence of IGF-I and insulin in the medium (BSA conditions), the number of neurons and glial cells was very low after 3-4 d of culture (Fig. 7). Addition of $100 \mathrm{ng} / \mathrm{ml}$ IGF-I caused a marked increase in the absolute numbers of neurons, astrocytes, and oligodendrocytes. Moreover, the proportion of TuJ1- plus GFAP- plus O4-positive cells was 4.5 -fold greater in IGF-I-treated cultures compared with the control BSA value. Under our culture conditions for OBSC differentiation (total absence of insulin and serum), it was not possible to distinguish an exclusive effect of exogenous IGF-I on differentiation from a combined differentiation plus survival effect. In fact, IGF-I treatment for only $15 \mathrm{hr}$ produced larger numbers of TuJ1-positive cells, as well as of total cell number, compared with control cultures (data not shown). These conditions differ from those described by Arsenijevic and Weiss (1998) on striatal stem cells, which included 1\% FBS in the differentiation medium. The minimum IGF-I dose augmenting the numbers of neurons, astrocytes, and oligodendrocytes was similar (Fig. 7A); however, the saturating concentration of IGF-I was $40 \mathrm{ng} / \mathrm{ml}$ for neurons and astrocytes and $\sim 200 \mathrm{ng} / \mathrm{ml}$ for oligodendrocytes (Fig. $7 A, B$ ). The strong IGF-I dependence of stem cell-generated neurons and astrocytes was further corroborated in experiments in which insulin or BDNF was added to cultures alone or in combination with IGF-I. As depicted (Fig. 7 B,C), $100 \mathrm{ng} / \mathrm{ml}$ insulin or $100 \mathrm{ng} / \mathrm{ml} \mathrm{BDNF}$ produced only small increases in the numbers of stem cell-derived neurons and glia, compared with the effects elicited by $100 \mathrm{ng} / \mathrm{ml}$ IGF-I or $10 \mu \mathrm{g} / \mathrm{ml}$ insulin. Moreover, the numbers of TuJ1- or GFAP-positive cells were similar in the cultures treated with IGF-I alone or with IGF-I plus insulin or IGF-I plus BDNF. Interestingly, the numbers of O4-positive cells were two- to 2.5 -fold greater $(p<0.01)$ in cultures treated with the combination of insulin plus IGF-I or BDNF plus IGF-I versus those treated with $100 \mathrm{ng} / \mathrm{ml}$ IGF-I (Fig. $7 \mathrm{~B}, \mathrm{C}$ ). OBSC-generated neurons and astrocytes are therefore markedly dependent on exogenous IGF-I for differentiation and survival, whereas oligodendrocytes are dependent on factors from various families.

Differentiation of stem cell-derived neurons and glia but not stem cell proliferation was compromised in cultures from the olfactory bulb of $I g f-I^{-1-}$ mice

The above results indicate that IGF-I and (pro)insulin have distinct, important roles and probably cooperate in vivo to control the number of OBSCs and their differentiated products. To determine whether endogenous IGF-I was absolutely required for stem cell proliferation and differentiation, cell cultures were prepared from the OB of E14.5 mutant mice lacking both copies of the Igf-I gene (null mutant) and of wild-type mice. Cultures were expanded in the presence of FGF-2 plus EGF plus insulin. Under these conditions, no differences in the number of nestin- or BrdU-positive cells were found between Igf- $I^{-1-}$ and $I g f-I^{+/+}$ cultures (data not shown). Moreover, the cell proliferation rate was not affected by the mutation, even when cells were cultured in the absence of insulin, maintaining EGF plus FGF-2 (Fig. 8A), or in the absence of insulin, EGF, and FGF-2 (data not shown); this indicates that endogenous IGF-I is not absolutely necessary 
to maintain $\mathrm{OB}$ stem cell proliferation. Cells were then induced to differentiate in the absence of insulin and mitogens for $3 \mathrm{~d}$ (Fig. $8 B, C$ ). The percentages of neurons, astrocytes, and oligodendrocytes in the $I g f-I^{-1-}$ cultures were reduced by 2.2-, 3.3-, and 4.8-fold, respectively, compared with the $I g f-I^{+/+}$cultures (Fig. 8 B). In accordance, the total proportion of positive TuJ1- plus GFAP- plus O4labeled cells was $14.3 \%$ in $I g f-I^{-1-}$ cultures and $34.9 \%$ in wild-type cultures. Nonetheless, total cell number was not significantly lower in cultures from null compared with those from wild-type mice (Fig. 8C). These results indicate that the progeny of OBSCs require endogenous IGF-I for differentiation in culture.

Absence of IGF-I causes neuronal and glial defects in the olfactory bulb in vivo To further establish that IGF-I is necessary for OB cell differentiation in vivo, sections obtained from E15.5-E18.5 Igf- $I^{-/-}$and $I g f-I^{+/+}$mice were analyzed. At E15.5, most of the mitral neurons have already generated in the mouse OB (Hinds, 1968a,b). At this age, two cell layers are prominent in the OB (Fig. $9 A-D$ ), one composed mostly of neuroepithelial cells, surrounding the ventricle, and a second layer that stains positively for calretinin. The calretinin-positive cells would correspond to immature mitral neurons (and in a lower proportion, to tufted neurons) (Bastianelli and Pochet, 1995). As shown, $\mathrm{H} \& \mathrm{E}$ and calretinin staining revealed no clear effect of the Igf-I deletion in OB cell organization at E15.5. Notably, $1 \mathrm{~d}$ later, at E16.5 (Fig. 9E,F), the wild-type OB shows a distinct mitral cell layer (MCL), apparently absent in the Igf-I null OB. Immunostaining with an antibody against neurotensin, a mitral neuron marker (Kiyama et al., 1991; Bulfone et al., 1998), revealed the presence of positive cells in the Igf-I null mouse OB, although they did not form a distinct MCL as observed in the wild-type mouse (data not shown). By the end of gestation, at E18.5 (Fig. 9G,H), there was a marked decrease in calretinin expression in the MCL in Igf- $I^{-/-}$embryos, whereas calretinin-positive cells were abundant in the MCL of wild-type embryos. No clear differences in calretinin expression were seen in the olfactory nerve layer or in the olfactory receptor neurons (data not shown) between the two genotypes, suggesting a specific effect of the Igf-I mutation on mitral neurons. GABA and tyrosine hydroxylase immunostaining of E18.5 sections did not reveal clear and consistent differences in the number and distribution of GABAergic and dopaminergic interneurons, respectively, between $I g f-I^{+/+}$ and $I g f-I^{-1-}$ mice at this age (data not shown). Nestin protein (Fig. 9I,J) was found primarily in neuroepithelial cells surround-

B
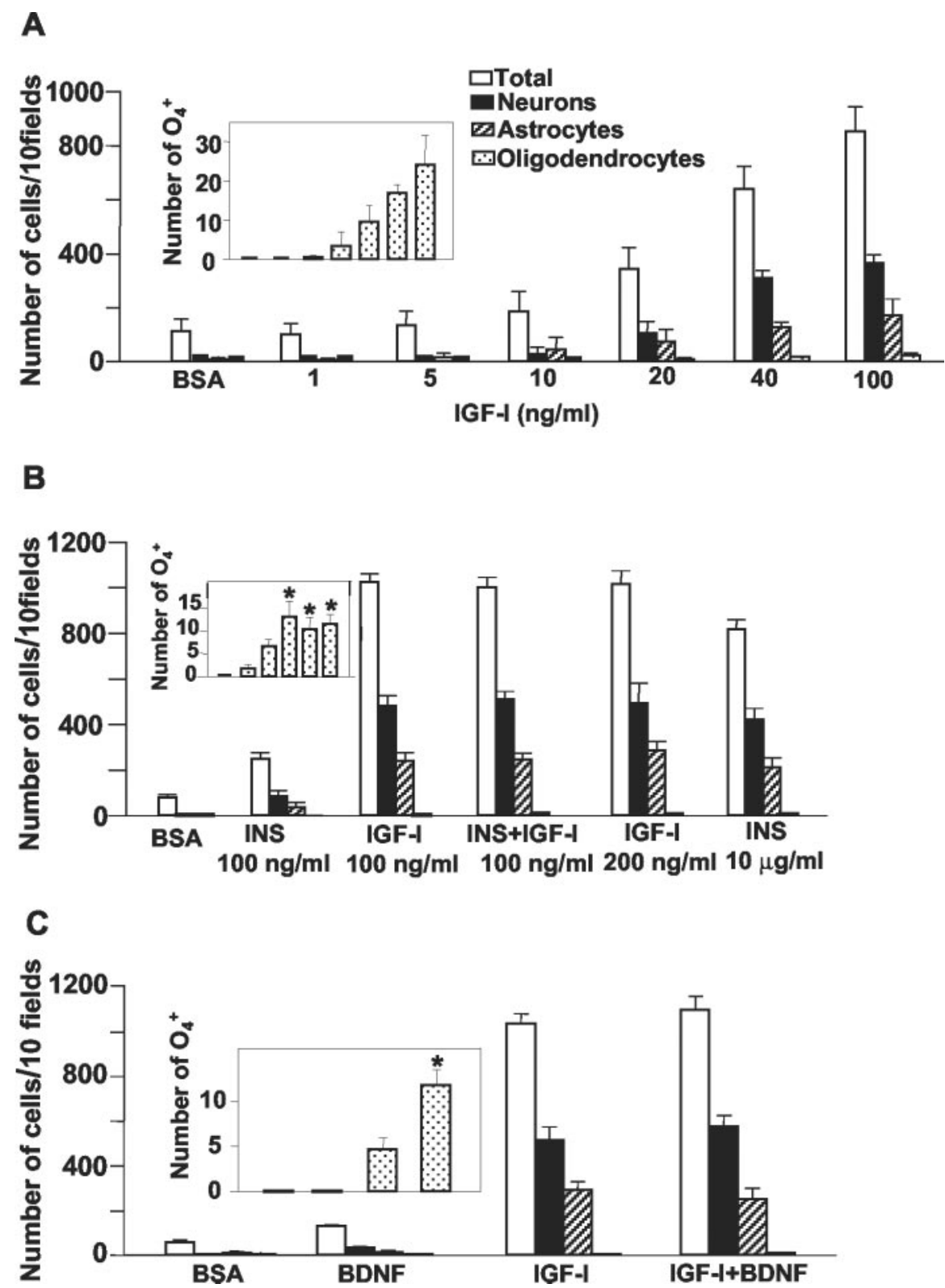

Figure 7. IGF-I effects on numbers of neurons and glia derived from olfactory bulb stem cells: cooperation with insulin and BDNF. E14.5-derived cells growing in the presence of FGF-2 plus EGF and insulin were plated in four-well chamber slides or glass coverslips for 3-4 $\mathrm{d}$ in the absence of insulin and mitogens. A, Dose-response curve of IGF-I effects on total cell number; TuJ1-, GFAP-, and 04-positive cells generated from OBSCs. Inset shows data for $04^{+}$in an expanded scale. Differences between 04 values with 40 and $100 \mathrm{ng} / \mathrm{ml} \mathrm{IGF-I} \mathrm{were} \mathrm{statistically} \mathrm{significant}\left({ }^{*} p<0.05\right)$. B, Effects of IGF-I, insulin (INS), and their combination on total cell number; TuJ1-, GFAP-, and 04-positive cells. Inset shows data for $04^{+}$. Statistical analysis for 04-positive cells:

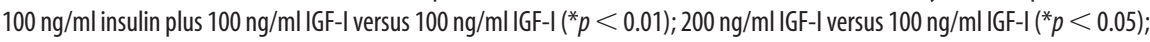
$10 \mu \mathrm{g} / \mathrm{ml}$ insulin versus $100 \mathrm{ng} / \mathrm{ml} \mathrm{IGF-I} \mathrm{(*} p<0.01$ ). C, Effects of IGF-I, BDNF, and their combination on total cell number; TuJ1-, GFAP-, and 04-positive cells. Inset shows data for $04^{+}$. Statistical analysis for $04-$ positive cells: $100 \mathrm{ng} / \mathrm{ml} \mathrm{BDNF} \mathrm{plus} 100 \mathrm{ng} / \mathrm{ml}$

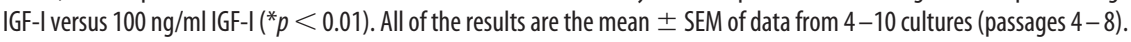

ing the lateral ventricle and in radial glia in the E15.5, E16.5 (data not shown), and E18.5 wild-type embryos. The MCL, in contrast, was nestin negative (Fig. 9I, arrowheads). In the Igf- $I^{+/+}$embryos, nestin expression displays a radial pattern, with branched processes of radial glia forming two dense plexus, one superficial to the MCL and a second deep to MCL, characteristic of olfactory bulb radial glia (Bailey et al., 1999; Puche and Shipley, 2001). This pattern was distorted in $I g f-I^{-/-}$mice, both in radial distribution and in the extent and morphology of the plexus, especially the superficial one (Fig. 9J), indicating that radial glia differentiation 


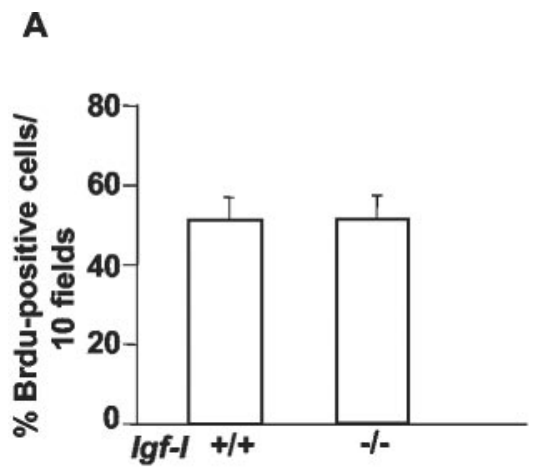

B
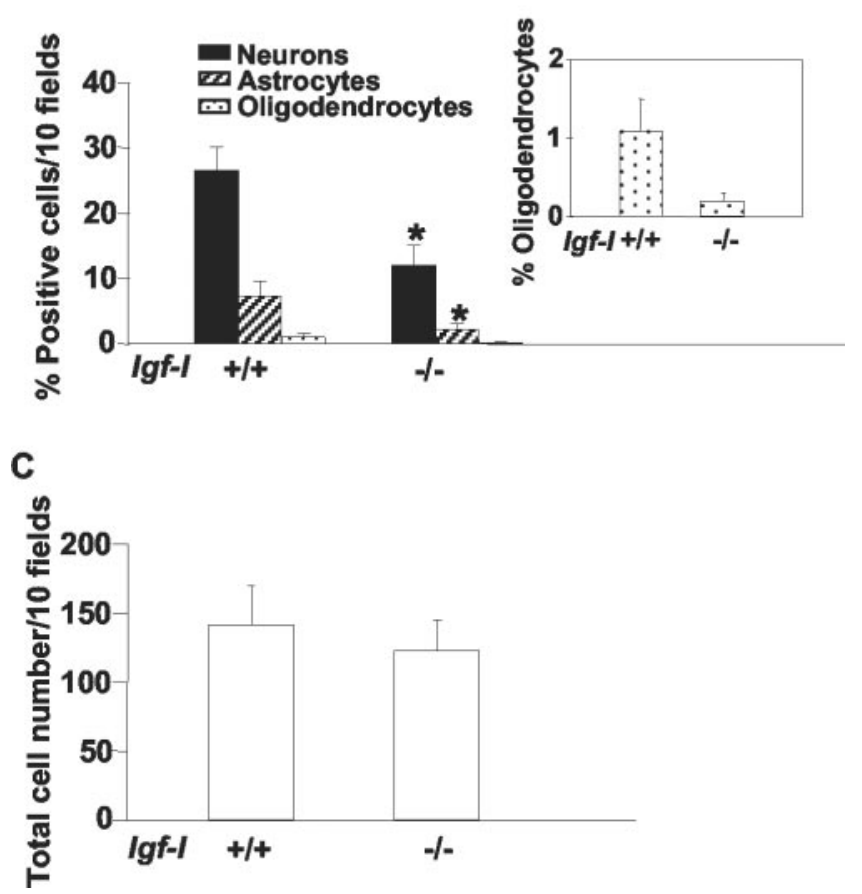

Figure 8. Differentiation of neurons and glia is impaired in olfactory bulb stem cell cultures from Igf-I $I^{-1-}$ mice. Cultures from individual E14.5 embryos were expanded in a medium containing FGF-2 plus EGF and $10 \mu \mathrm{g} / \mathrm{ml}$ insulin. Cells were then allowed to proliferate $(A)$ or, after mitogen withdrawal, to differentiate $(B, C)$ for $3-4 d$ in the absence of insulin. Cells were immunostained using BrdU, TuJ1, GFAP, or 04 primary antibodies. Results are expressed as percentage of BrdU-positive cells ( $A$ ), percentage of TuJ1-, GFAP-, or 04-positive cells ( $B$ ) (inset shows data for $\mathrm{O4}^{+}$in an expanded scale), and total cell number $(C)$ and are the mean \pm SEM of data from 6-12 cultures of three to six embryos per value (passages 5-9). Statistically significant differences $\left({ }^{*} p<0.001\right)$ between $/ g f-I^{-1-}$ and $I g f-I^{+/+}$cells.

was impaired as a consequence of the lack of IGF-I. The use of an antibody against GFAP did not reveal OB astrocytes at E18.5, although GFAP-positive cells were found in the hippocampal fimbria and in the spinal cord (data not shown).

\section{Discussion}

Multipotent stem cells can be isolated from the mouse embryonic olfactory bulb

Here we report the isolation and characterization of stem cells locally born in the early embryonic mouse OB. Two facts support the conclusion that the OB neuroepithelium and not the SVZRMS is the source of the stem cells. First, cells having stem cell features can be isolated from the E12.5 and E13.5 OB, two ages at which no SVZ is observed in the OB, and not only from the E14.5 $\mathrm{OB}$, the age at which the SVZ is first detected in the OB. The
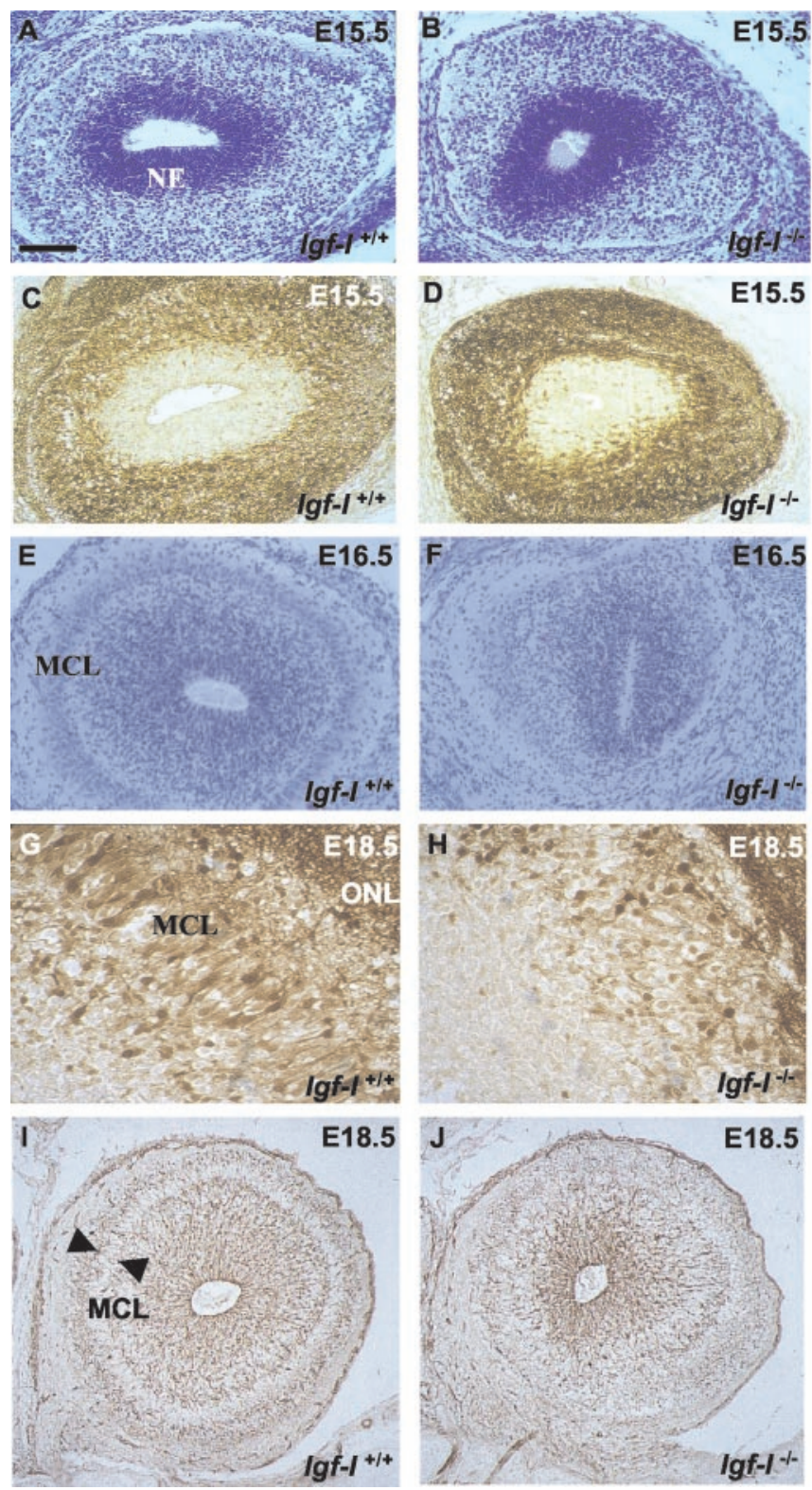

Figure 9. Mitral cell layer formation and radial glia differentiation are disrupted in the olfactory bulb of $I g f-I^{-1}$ mice. Sections from E15.5, E16.5, and E18.5 Igf- $I^{+/+}$and $/ g f-I^{-I-}$ mouse olfactory bulb were stained with $\mathrm{H \& E}(A, B, E, F)$ or immunostained with antibodies against calretinin $(C, D, G, H)$ or nestin $(I, J)$. In the absence of IGF-I, formation of the mitral cell layer $(M C L)(E-H)$ and radial glia differentiation $(I, J)$ are disrupted. No major differences in the cellular organization of the olfactory bulb between the two genotypes were observed at E15.5 $(A-D)$. Similar phenotype was observed in two to four animals per genotype. $N E$, Neuroepithelial cells; ONL, olfactory nerve layer. Scale bar (shown in A): $A-F, 25 \mu \mathrm{m} ; G, H, 10 \mu \mathrm{m} ; I, J, 30 \mu \mathrm{m}$.

germinal zone surrounding the $\mathrm{E} 14.5 \mathrm{OB}$ ventricle in fact consists primarily of a layer of neuroepithelial cells, whereas the SVZ becomes prominent after E17-E18 (Hinds 1968b; Altman and Bayer, 1995; our observations). Second, under proliferative conditions, $\beta$-III-tubulin-positive cells, a characteristic feature of SVZ-RMS-derived neuroblasts (Menezes and Luskin, 1994), and GFAP-positive cells, a feature of adult SVZ stem cells (Doetsch et al., 1999), were nearly absent from the cultures.

Embryonic OBSC cells can divide in culture for at least 5.5 months, and clonal analysis demonstrates that $61.1 \%$ of differentiated clones contain neurons, astrocytes, and oligodendrocytes. Clonal analysis also confirms the existence within the spheres of 
fate-restricted proliferative precursor cells, which was observed previously in stem cell cultures from other brain regions (Davis and Temple, 1994; Reynolds and Weiss, 1996; Arsenijevic et al., 2001). Remarkably, embryonic OBSCs gave rise to greater numbers of neurons than of astrocytes or oligodendrocytes, at least up to passage 23 (3 months). Even after passage 40 (5.5 months in culture), they maintain the potential to differentiate into neurons and glia. These results indicate that under our culture conditions, OBSCs retain their differentiative potential for long periods of time. Astrocytes were nonetheless the major cell population that originated from adult OB stem cells (Gritti et al., 2002). It would be important to determine whether the distinct potential of embryonic and adult $\mathrm{OB}$ stem cells reflects a change in the cells' ability to integrate extracellular and intracellular signals responsible for cell fate decisions. Our results support the existence of stem cells in the mouse embryo $\mathrm{OB}$ with the potential to generate various types of glial as well as neuronal cells, the latter indicated by the presence of calretinin- and GABA-positive cells in the cultures. The finding of stem cells in the embryonic and adult $\mathrm{OB}$ opens the question as to whether they are lineage related. Whether the radial glia is a cell type intermediate between embryonic and adult stem cells (Alvarez-Buylla et al., 2001) that could function as a repository pool needs to be investigated.

\section{Cooperative interplay of growth factors stimulates OBSC proliferation in culture}

We report that in the absence of insulin-related growth factors, the proliferative and sphere formation potential of FGF-2 and EGF on olfactory bulb stem cells diminishes markedly, and that this potential can be rescued by addition of IGF-I and insulin, as well as by proinsulin. These results support cooperative interplay between IGF-I and (pro)insulin together with FGF-2 plus EGF, which is critical for optimal levels of OBSC proliferation in culture. The fact that IGF-I and (pro)insulin increase the percentage of proliferative cells as well as the total cell number in FGF-2 plus EGF-treated cultures suggests that these effects may be mediated by mechanisms accelerating cell entry into the $S$ phase of the cell cycle or preventing apoptosis as reported in other cell systems (Díaz et al., 2000; Jiang et al., 2001).

Arsenijevic et al. (2001) recently reported that in the absence of IGF-I, EGF or FGF-2 was unable to stimulate sphere formation of embryonic striatal cells; however, removal of IGF-I and (pro)insulin from OBSC cultures slowed down but did not block sphere formation promoted by FGF-2 plus EGF. Thus, stem cells from dorsal $(\mathrm{OB})$ and ventral (striatum) telencephalic regions have slightly different growth factor requirements for proliferation. The data from both groups nevertheless reinforce a role for IGF-I in regulating stem cell number in culture, and our data extend this role to insulin and its precursor, proinsulin. In support of a role for IGF-I in stem and precursor cell proliferation, this factor promotes neurogenesis in the adult dentate gyrus (Aberg et al., 2000; Trejo et al., 2001). Our results demonstrate, however, that stem cell proliferation can progress in the absence of IGF-I. Ongoing studies should clarify whether other insulinrelated growth factors can compensate for the lack of IGF-I in maintaining cell proliferation. The fact that OBSCs express (pro)insulin and IGF-II at the mRNA and protein levels, in addition to IGF-I, supports this possibility. These results together with data from Arsenijevic et al. (2001) reporting that endogenous IGF-I was necessary for EGF- but not for FGF-2-promoting neurosphere formation, and from Cheng et al. (2001) reporting that cell proliferation in the dentate gyrus was not reduced in Igf-I null mice, should encourage further studies on the function of
IGF-I and other insulin-related growth factors during stem cell proliferation in vivo.

The observations that IGF-I has a significant effect on OB cell proliferation whereas insulin has no effect, even at a very high concentration, and that effects of insulin plus IGF-I are similar to those of IGF-I (Fig. 4), suggest that in OBSCs, signals from the insulin-related growth factors are mediated primarily by the IGFIR. A possible upregulation of IGF-IR levels by FGF-2 (Hernández-Sánchez et al., 1997) would facilitate (pro)insulin interaction with the IGF-IR. Two observations nonetheless suggest implication of the InsR, as a typical dimer or forming molecular hybrids with the IGF-IR, during OBSC proliferation. First, insulin and proinsulin elicit a synergistic response when added to FGF-2 plus EGF, whereas IGF-I only elicits an additive response; this may be interpreted as the activation of the InsR or hybrids in the first case and the IGF-IR in response to IGF-I. Second, immunocytochemical data and preliminary RT-PCR data (Hernández-Sánchez, Yusta-Boyo, Vicario-Abejón, de Pablo, unpublished observations) indicate that OBSCs express InsR as well as IGF-IR. In any case, the signaling cascade should converge, because addition of $100 \mathrm{ng} / \mathrm{ml}$ insulin does not increase the effects of $100 \mathrm{ng} / \mathrm{ml}$ IGF-I. Whether the InsR plays a specific role in oligodendrocyte differentiation, as suggested by the distinct response of this cell population to insulin and IGF-I, remains to be studied.

\section{Endogenous IGF-I is required for differentiation of OB stem/} precursor cell-derived neurons and glia in culture and in vivo Short-term IGF-I treatment, after mitogen withdrawal from OBSCs, produced greater numbers of TuJ1-positive cells and total cells compared with control cultures. This fact suggests that exogenous IGF-I may act as a differentiation as well as a survival factor. Nonetheless, the data showed that the percentages of TuJ1-, GFAP-, and O4-positive cells were markedly lower in the $I g f-I^{-/-}$cultures compared with $I g f-I^{+/+}$, whereas total cell numbers were similar. This supports a specific role for endogenous IGF-I in OBSC differentiation, probably acting in an autocrine/paracrine manner. In accordance, formation of the MCL and morphological differentiation of radial glia is impaired in the Igf- $I^{-/-}$mice.

Although the numbers of OBSC-derived neurons, astrocytes, and oligodendrocytes are all IGF-I dependent, we found cell-specific characteristics in these responses. In particular, higher concentrations of exogenous IGF-I are necessary for maximal numbers of oligodendrocytes, in comparison with those of neurons or astrocytes. This may explain the synergistic effects of insulin and IGF-I or, more markedly, of BDNF and IGF-I in promoting oligodendrocyte development. The effect of BDNF on OBSCderived oligodendrocytes is specific to this cell population, because BDNF alone or in combination with IGF-I has only a minimum effect on neuron or astrocyte numbers. This differs from the reported action of BDNF in promoting survival and differentiation of hippocampal (Vicario-Abejón et al., 1995, 2000) and striatal neuronal precursors (Ahmed et al., 1995; Arsenijevic and Weiss, 1998). In contrast, IGF-I is the most potent factor in promoting differentiation of neurons generated from OBSCs.

The in vivo analysis further supports the strong dependence of OB cells on IGF-I for complete differentiation; indeed, postmitotic mitral neurons appear to be generated in Igf-I null mice, but their allocation into an organized MCL is disrupted. A previous work reported specific depletion of mitral neurons in the $\mathrm{OB}$ of adult IGF-I null mice, but the reason for this was not described 
(Cheng at al., 1998). Our data suggest that mitral neuron depletion in the Igf-I $I^{-1-}$ may be secondary to the alteration of cell allocation. The MCL disorganization may be the cause or the consequence of the altered radial glia morphology, because formation of the two plexus of radial glia in the OB appears to concur with the presence of a distinct MCL (Bailey et al., 1999; Puche and Shipley 2001). Although the molecular events involved in MCL formation and radial glia differentiation, as well as the role of radial glia, are poorly understood, it is noteworthy that in the cortex, radial glia differentiation is dependent on the secreted protein reelin (Super et al., 2000). Because mitral neurons express reelin mRNA (Alcántara et al., 1998) and reelin plays a role in OB development (Kim et al., 2002), it is tempting to speculate that reelin, secreted by mitral neurons, may support the differentiation of radial glia in the OB and that absence of IGF-I may cause deregulation of the reelin pathway. Alternatively, an initial defect in radial glia differentiation, a consequence of the lack of IGF-I, may produce an alteration in mitral cell allocation into a precise layer, because it is suggested that $\mathrm{OB}$ radial glial may provide scaffolds for neuronal migration (Puche and Shipley, 2001). The OB is unique among brain structures expressing IGF-I high levels throughout life, particularly the mitral neurons (Bondy, 1991). Our results show that the OB has developed to acquire an exquisite dependence on IGF-I from early neurogenesis onward. The presence of stem cells in the $\mathrm{OB}$ opens up the possibility of studying whether OBSCs are a suitable source of diverse cell types for transplantation-based therapies of neurodegenerative diseases or CNS lesions.

\section{References}

Aberg MAI, Aberg ND, Hedbäcker H, Oscarsson J, Eriksson PS (2000) Peripheral infusion of IGF-I selectively induces neurogenesis in the adult rat hippocampus. J Neurosci 20:2896-2903.

Ahmed S, Reynolds A, Weiss S (1995) BDNF enhances the differentiation but not the survival of CNS stem cell-derived neuronal precursors. J Neurosci 15:5765-5778.

Alarcón C, Serna J, Pérez-Villamil B, De Pablo F (1998) Synthesis and differentially regulated processing of proinsulin in developing chick pancreas, liver and neuroretina. FEBS Lett 436:361-366.

Alcántara S, Ruiz M, D'Arcangelo G, Ezan F, De Lecea L, Curran T, Sotelo C, Soriano E (1998) Regional and cellular patterns of reelin mRNA expression in the forebrain of the developing and adult mouse. J Neurosci 18:7779-7799.

Altman J, Bayer SA (1995) Atlas of prenatal rat brain development. Boca Raton, FL: CRC.

Alvarez-Buylla A, Garcia-Verdugo JM, Tramontin AD (2001) A unified hypothesis on the lineage of neural stem cells. Nat Rev Neurosci 2:287-293.

Anderson DJ (2001) Stem cells and pattern formation in the nervous system: the possible versus the actual. Neuron 30:19-35.

Arsenijevic Y, Weiss S (1998) Insulin-like growth factor-I is a differentiation factor for postmitotic CNS stem cell-derived neuronal precursors: distinct actions from those of brain-derived neurotrophic factor. J Neurosci $18: 2118-2128$.

Arsenijevic Y, Weiss S, Schneider B, Aebisher P (2001) Insulin-like growth factor-I is necessary for stem cell proliferation and demonstrates distinct actions of epidermal growth factor and fibroblast growth factor-2. J Neurosci 15:7194-7202.

Bailey MS, Puche AC, Shipley MT (1999) Development of the olfactory bulb: evidence for glia-neuron interactions in glomerular formation. J Comp Neurol 415:423-448.

Bastianelli E, Pochet R (1995) Calmodulin, calbindin-D28k, calretinin and neurocalcin in rat olfactory bulb during postnatal development. Dev Brain Res 87:224-227.

Beck KD, Powell-Braxton L, Widmer HR, Valverde J, Hefti F (1995) Igf1 gene disruption results in reduced brain size, CNS hypomyelination, and loss of hippocampal granule and striatal parvalbumin-containing neurons. Neuron 14:717-730.

Benraiss A, Chmielnicki E, Lerner K, Roh D, Goldman SA (2001) Adenovi- ral brain-derived neurotrophic factor induces both neostriatal and olfactory neuronal recruitment from endogenous progenitor cells in the adult forebrain. J Neurosci 21:6718-6731.

Bondy CA (1991) Transient IGF-I gene expression during the maturation of functionally related central projection neurons. J Neurosci 11:3442-3455.

Brooker GJF, Kalloniatis M, Russo VC, Murphy M, Werther GA, Bartlett PF (2000) Endogenous IGF-1 regulates the neuronal differentiation of adult stem cells. J Neurosci Res 59:332-341.

Bulfone A, Wang F, Hevner R, Anderson S, Cutforth T, Chen S, Meneses J, Pedersen R, Axel R, Rubenstein JLR (1998) An olfactory sensory map develops in the absence of normal projection neurons or GABAergic interneurons. Neuron 21:1273-1282.

Camarero G, Avendaño C, Fernández-Moreno C, Villar A, Contreras J, De Pablo F, Pichel JG, Varela-Nieto I (2001) Delayed inner ear maturation and neuronal loss in postnatal IGF-1-deficient mice. J Neurosci 21:7630-7641.

Capela A, Temple S (2002) LeX/ssea-1 is expressed by adult mouse CNS stem cells, identifying them as nonependymal. Neuron 35:865-875.

Cheng CM, Joncas G, Reinhardt RR, Farrer R, Quarles R, Janssen J, McDonald MP, Crawley JN, Powell-Braxton L, Bondy CA (1998) Biochemical and morphometric analyses show that myelination in the insulin-like growth factor 1 null brain is proportionate to its neuronal composition. J Neurosci 18:5673-5681.

Cheng CM, Cohen M, Tseng V, Bondy CA (2001) Endogenous IGF1 enhances cell survival in the postnatal dentate gyrus. J Neurosci Res 64:341-347.

Chiasson BJ, Tropepe V, Morshead CM, van der Koy D (1999) Adult mammalian forebrain ependymal and subependymal cells demonstrate proliferative potential, but only subependymal cells have stem cell characteristics. J Neurosci 19:4462-4471.

Ciccolini F, Svendsen CN (1998) Fibroblast growth factor 2 (FGF-2) promotes acquisition of epidermal growth factor (EGF) responsiveness in mouse striatal precursor cells: identification of neural precursors responding to both EGF and FGF-2. J Neurosci 18:7869-7880.

Davis AA, Temple S (1994) A self-renewing multipotential stem cell in embryonic rat cerebral cortex. Nature 372:263-266.

de la Rosa E, De Pablo F (2000) Cell death in early neural development: beyond the neurotrophic theory. Trends Neurosci 23:454-458.

De Pablo F, de la Rosa EJ (1995) The developing CNS: a scenario for the action of proinsulin, insulin and insulin-like growth factors. Trends Neurosci 18:143-150.

Díaz B, Serna J, De Pablo F, de la Rosa EJ (2000) In vivo regulation of cell death by embryonic (pro)insulin and the insulin receptor during early retinal neurogenesis. Development 127:1641-1649.

Doetsch F, Caillé I, Lim DA, García-Verdugo JM, Alvarez-Buylla A (1999) Subventricular zone astrocytes are neural stem cells in the adult mammalian brain. Cell 97:703-716.

Drago J, Murphy M, Carroll SM, Harvey R, Bartlett PF (1991) Fibroblast growth factor-mediated proliferation of central nervous system precursors depends on endogenous production of insulin-like growth factor I. Proc Natl Acad Sci USA 88:2199-2203.

Edlund T, Jessell TM (1999) Progression from extrinsic to intrinsic signaling in cell fate specification: a view from the nervous system. Cell 96:211-224.

Gage FH (2000) Mammalian neural stem cells. Science 287:143-148.

Gritti A, Parati EA, Cova L, Frolichsthal P, Galli R, Wanke E, Faravelli L, Morassutti DJ, Roisen F, Nickel DD, Vescovi AL (1996) Multipotential stem cells from the adult mouse brain proliferate and self-renew in response to basic fibroblast growth factor. J Neurosci 16:1091-1100.

Gritti A, Bonfanti L, Doetsch F, Caille I, Alvarez-Buylla A, Lim DL, Galli R, Garcia Verdugo JM, Herrera DG, Vescovi AL (2002) Multipotent neural stem cells reside in the rostral extension and olfactory bulb of adult rodents. J Neurosci 22:437-445.

Hernández-Sánchez C, Werner H, Roberts Jr CT, Woo EJ, Hum DW, Rosenthal SM, LeRoith D (1997) Differential regulation of insulin-like growth factor-I (IGF-I) receptor gene expression by IGF-I and basic fibroblastic growth factor. J Biol Chem 272:4663-4670.

Herrera R, Petruzzelli L, Thomas N, Bramson NH, Kaiser ET, Rosen OM (1985) An antipeptide antibody that specifically inhibits insulin receptor autophosphorylation and protein kinase activity. Proc Natl Acad Sci USA 82:7899-7903.

Hinds JW (1968a) Autoradiographic study of histogenesis in the mouse ol- 
factory bulb I. Time of origin of neurons and neuroglia. J Comp Neurol 134:287-304.

Hinds JW (1968b) Autoradiographic study of histogenesis in the mouse olfactory bulb II. Cell proliferation and migration. J Comp Neurol 134:305-322.

Jacobson MJ (1991) Developmental neurobiology. New York: Plenum.

Jiang F, Frederick TJ, Wood TL (2001) IGF-I synergizes with FGF-2 to stimulate oligodendrocyte progenitor entry into the cell cycle. Dev Biol 232:414-423.

Johansson CB, Momma S, Clarke DL, Risling M, Lendahl U, Frisen J (1999) Identification of a neural stem cell in the adult mammalian central nervous system. Cell 96:25-34.

Johe KK, Hazel TG, Muller T, Dugich-Djordjevic MM, McKay RDG (1996) Single factors direct the differentiation of stem cells from the fetal and adult central nervous system. Genes Dev 10:3129-3140.

Kim HM, Qu T, Kriho V, Lacor P, Smalheiser N, Pappas GD, Guidotti A, Costa E, Sugaya K (2002) Reelin function in stem cell biology. Proc Natl Acad Sci USA 99:4020-4025.

Kiyama H, Sato M, Emson PC, Tohyama M (1991) Transient expression of neurotensin mRNA in the mitral cells of rat olfactory bulb during development. Neurosci Lett 128:85-89.

Kornack DR, Rakic P (2001) The generation, migration, and differentiation of olfactory neurons in the adult primate brain. Proc Natl Acad Sci USA 98:4752-4757.

Lillien L (1998) Neural progenitors and stem cells: mechanisms of progenitor heterogeneity. Curr Opin Neurobiol 8:37-44.

Liu JP, Baker, Perkins AS, Robertson EJ, Efstratiadis A (1993) Mice carrying null mutations of the genes encoding insulin-like growth factor I (Igf-1) and type 1 IGF receptor (Igf1r). Cell 75:59-72.

Luskin MB (1993) Restricted proliferation and migration of postnatally generated neurons derived from the forebrain subventricular zone. Neuron 11:173-189.

McKay R (1997) Stem cells in the central nervous system. Science 276:66-71.

Menezes JR, Luskin MB (1994) Expression of neuron-specific tubulin defines a novel population in the proliferative layers of the developing telencephalon. J Neurosci 14:5399-5416.

Pagano SF, Impagnatiello F, Girelli M, Cova L, Grioni E, Onofri M, Cavallaro M, Etteri S, Vitello F, Giombini S, Solero CL, Parati EA (2000) Isolation and characterization of neural stem cells from the adult human olfactory bulb. Stem Cells 18:295-300.
Pencea V, Bingaman KD, Wiegand S, Luskin MB (2001) Infusion of brainderived neurotrophic factor into the lateral ventricle of the adult rat leads to new neurons in the parenchyma of the striatum, septum, thalamus, and hypothalamus. J Neurosci 21:6706-6717.

Pichel JG, Fernández-Moreno C, Vicario-Abejón C, Sánchez-Testillano P, Patterson PM, De Pablo F (2003) Developmental cooperation of Lif and IGF-I in mice is tissue-specific and essential for lung maturation involving the transcription factors Sp3 and TTF-1. Mech Dev, in press.

Puche AC, Shipley MT (2001) Radial glia development in the mouse olfactory bulb. J Comp Neurol 434:1-12.

Qian X, Shen Q, Goderie SK, He W, Capela A, Davis AA, Temple S (2000) Timing of CNS cell generation: a programmed sequence of neuron and glial cell production from isolated murine cortical stem cells. Neuron 28:69-80.

Quiroga S, Garofalo RS, Pfenninger KH (1995) Insulin-like growth factor I receptors of fetal brain are enriched in nerve growth cones and contain a $\beta$-subunit variant. Proc Natl Acad Sci USA 92:4309-4312.

Reynolds A, Weiss S (1996) Clonal and population analyses demonstrate that an EGF-responsive mammalian embryonic CNS precursor is a stem cell. Dev Biol 175:1-13.

Rietze RL, Valcanis H, Broker GF, Thomas T, Voss A, Bartlett P (2001) Purification of pluripotent neural stem cells from the adult mouse brain. Nature 412:736-739.

Super H, Del Río JA, Martínez A, Perez-Sust P, Soriano E (2000) Disruption of neuronal migration and radial glia in the developing cerebral cortex following ablation of Cajal-Retzius cells. Cereb Cortex 10:602-613.

Temple S (2001) The development of neural stem cells. Nature 414: $112-117$.

Trejo JL, Carro E, Torres-Alemán I (2001) Circulating insulin-like growth factor I mediates exercise-induced increases in the number of new neurons in the adult hippocampus. J Neurosci 21:1628-1634.

Tropepe V, Hitoshi S, Sirard C, Mak TW, Rossant J, van der Kooy D (2001) Direct neural fate specification from embryonic stem cells: a primitive mammalian neural stem cell stage acquired through a default mechanism. Neuron 30:65-78.

Vicario-Abejón C, Johe KK, Hazel TG, Collazo D, McKay RDG (1995) Functions of basic-fibroblast growth factor and neurotrophins in the differentiation of hippocampal neurons. Neuron 15:105-114.

Vicario-Abejón C, Collin C, Tsoulfas P, McKay RDG (2000) Hippocampal stem cells differentiate into excitatory and inhibitory neurons. Eur J Neurosci 12:677-688. 